\title{
Ammonia and carbon dioxide emissions by stabilized conventional nitrogen fertilizers and controlled release in corn crop
}

\author{
Emissões de amônia e de dióxido de carbono de fertilizantes nitrogenados \\ convencionais, estabilizados e liberação controlada na cultura do milho
}

\author{
Taylor Lima de Souza ${ }^{1 *}$, Douglas Ramos Guelfi ${ }^{1}$, André Leite Silva ${ }^{1}$, André Baldansi Andrade ${ }^{1}$, \\ Wantuir Filipe Teixeira Chagas ${ }^{1}$, Eduardo Lopes Cancellier ${ }^{1}$
}

\author{
${ }^{1}$ Universidade Federal de Lavras/UFLA, Departamento de Ciência do Solo/DCS, Lavras, MG, Brasil \\ *Corresponding author: taylor.lima@gmail.com \\ Received in February 15, 2017 and approved in April 24, 2017
}

\begin{abstract}
The market of stabilized, slow and controlled release nitrogen $(\mathrm{N})$ fertilizers represents $1 \%$ of the world fertilizer consumption. On the other hand, the increase in availability, innovation and application of these technologies could lead to the improvement of $\mathrm{N}$ use efficiency in agroecossystems and to the reduction of environmental impacts. The objective of this study was to quantify agronomic efficiency relative index, ammonia volatilization, and $\mathrm{CO}_{2}$ emissions from conventional, stabilized and controlled release $\mathrm{N}$ fertilizers in corn summer crop. The experiment was carried out in a corn crop area located in Lavras, state of Minas Gerais, Brazil, without irrigation. All treatments were applied in topdressing at rate of $150 \mathrm{~kg} \mathrm{ha}^{-1} \mathrm{~N}$. N-NH $\mathrm{N}_{3}$ losses from N fertilizers were: Granular urea (39\% of the applied $\left.\mathrm{N}\right)=$ prilled urea $(38 \%)>$ urea coated with $16 \% \mathrm{~S}^{0}(32 \%)=$ blend of urea $+7.9 \% \mathrm{~S}^{0}+$ polymers + conventional urea $(32 \%)>$ prilled urea incorporated at $0.02 \mathrm{~m}$ depth $(24 \%)$ $>$ urea $+530 \mathrm{mg} \mathrm{kg}^{-1}$ of NBPT ( $\left.8 \%\right)=$ Hydrolyzed leather $(9 \%)>$ urea + thermoplastic resin $(3 \%)=$ ammonium sulfate $(1 \%)=$ ammonium nitrate (0.7\%). Thermoplastic resin coated urea, ammonium nitrate and ammonium sulfate presented low values of cumulative $\mathrm{CO}_{2}$ emissions in corn crop. On the other hand, hydrolyzed leather promoted greater $\mathrm{C}_{-} \mathrm{CO}_{2}$ emission, when compared with other nitrogen fertilizers.
\end{abstract}

Index terms: $\mathrm{CO}_{2} ; \mathrm{NH}_{3}$ loss; no-tillage; Zea mays $\mathrm{L}$.

\begin{abstract}
RESUMO
O consumo de fertilizantes nitrogenados estabilizados, de liberação lenta e controlada representa $1 \%$ do total de fertilizantes utilizados no mundo. Por outro lado, um aumento na disponibilidade, inovação e utilização dessas tecnologias pode levar a maior eficiência no uso do nitrogênio $(\mathrm{N})$ na agricultura com menor impacto ambiental. O objetivo deste trabalho foi quantificar as perdas de amônia $\left(\mathrm{N}-\mathrm{NH}_{3}\right)$ por volatilização e as emissões de $\mathrm{CO}_{2}$ de fertilizantes nitrogenados convencionais, estabilizados e de liberação controlada na cultura do milho. O experimento foi realizado em condições de campo no município de Lavras (MG) no ano agrícola 2013/2014, sem irrigação. Os tratamentos foram compostos por fertilizantes nitrogenados aplicadas em cobertura na dose de $150 \mathrm{~kg} \mathrm{ha}^{-1} \mathrm{de} \mathrm{N}$. A perda acumulada de $\mathrm{N}-\mathrm{NH}_{3}$ dos fertilizantes nitrogenados convencionais, estabilizados de liberação controlada em ordem decrescente foi: Ureia granulada $(39 \%$ do $\mathrm{N}$ aplicado $)=$ ureia perolada $(38 \%)>$ ureia $+16 \%$ de $\mathrm{S}^{0}(32 \%)=$ mistura física de grânulos (blend) de ureia revestida com $\mathrm{S}^{0} \mathrm{e}$ polímeros e ureia convencional $(32 \%)>$ ureia perolada incorporada $(24 \%)>$ ureia $+530 \mathrm{mg} \mathrm{kg}^{-1}$ de NBPT $(8 \%)=$ hidrolisado de couro bovino $(9 \%)>$ ureia + resina termoplástica $(3 \%)$ = sulfato de amônio $(1 \%)=$ nitrato de amônio $(0,7 \%)$. O sulfato e nitrato de amônio e a ureia + resina termoplástica promovem a menor emissão de dióxido de carbono $\left(\mathrm{C}-\mathrm{CO}_{2}\right)$ em área de cultivo de milho. Enquanto que, o hidrolisado de couro promoveu a maior emissão total de $\mathrm{C}-\mathrm{CO}_{2}$ para à atmosfera.
\end{abstract}

Termos para indexação: $\mathrm{CO}_{2}$; perdas de $\mathrm{NH}_{3}$; plantio direto; Zea mays $\mathrm{L}$.

\section{INTRODUCTION}

U rea is often applied to corn crops when environmental conditions are inappropriate. This reflects in yield reduction and extra costs due to the inefficient use of fertilizer and to $\mathrm{N}-\mathrm{NH}_{3}$ losses (Van Grinsven et al., 2015). B etween 20 to $70 \%$ of conventional urea applied escapes to the environment through ammonia volatilization and denitrification (Nauz; Sulaiman, 2016). In agricultural systems, several factors, such as humidity, temperature, $\mathrm{pH}$, organic matter, cultivation system, nitrogen (N) availability, and the $\mathrm{N}$ rates applied influence ammonia loss (Denmead; Freney; Dunin, 2008; Rochette et al., 2014; Cancellier et al., 2016) and $\mathrm{C}-\mathrm{CO}_{2}$ losses (Al-Kaisi et al., 2008).

In addition to the conventional alternatives already known to reduce $\mathrm{N}-\mathrm{NH}_{3}$ losse, such as: incorporation of urea (mechanically or by the water from irrigation and rain); (Holcomb et al., 2011; Rochette et al., 2014), and the supply of $\mathrm{N}$ in the form of nitrate or ammonium sulfate 
(Fontoura; Bayer, 2010), it should be mentioned the use of stabilized and of slow and controlled release nitrogen fertilizer (Azeem et al., 2014; Timilsena et al., 2014; Nauz; Sulaiman, 2016) which are within the scope of the " $4 C$ " practices - four management practices that promote the efficient use of fertilizer: to apply the right $\mathrm{N}$ source at the right dose, at the right time and the right place (Fixen 2007; Chien; Prochnow; Cantarella, 2009; IFA, 2009). Besides improving their agronomic efficiency, fertilizers that use this type of technology can help reducing emissions of greenhouse gases, such as nitrous oxide and carbon dioxide (Al-Kaisi et al., 2008; Halvorson et al., 2014; Fernández; Terry; Coronel, 2015; Gao et al., 2015).

Based on the type of technology used during the production process of $\mathrm{N}$ fertilizers, they were divided into three groups. The first group consists of slow release fertilizers, or chemically modified, such as urea formaldehyde. In this technology, urea reacts with the formaldehyde in a reactor under controlled conditions, forming chain molecules with greater size, with interleaved carbon $(\mathrm{C})$ and $\mathrm{N}$ atoms. In this form, $\mathrm{N}$ has gradual release to the soil, which is influenced by microbiological activity, temperature, acidity and soil moisture (Azeem et al., 2014; Timilsena et al., 2014; Yamamoto et al., 2016).

Controlled-release fertilizer belong to another group, in which the fertilizers are coated with resin, elemental sulfur $\left(\mathrm{S}^{0}\right)$ and polymers that control the release of $\mathrm{N}$ to the soil solution by diffusion, according by the Fick Law (A zeem et al., 2014). The first $S^{0}$ - coated urea was developed and patented in 1967 by the Tennessee Valley Authority (TVA), Muscle Shoals, Alabama, as an effective cost method to reduce urea particles dissolution for the application to the soil, and to aggregate sulfur, a macronutrient, to the granule for the distribution together with urea (Blouin, 1967). However, subsequent results of this work (Blouin; Rindt; Moore, 1971) showed the need of sealent application to correct imperfections in the $\mathrm{S}^{0}$ layer in order to reduce the desuniformity of granules coating (variation in thickness of the $\mathrm{S}^{0}$ coating between granules), promoting a "burst effect" (initial rapid release of nitrogen), followed by the "lock-off" (very slow release) (Azeem et al., 2014). There are problems inherent to $\mathrm{S}^{0}$ coated fertilizers, and the most concerning is the occurrence of undesirable forms of sulfur that promote cracks in the coating, resulting in losses in the ability of creating a barrier for water penetration and, and consequently, in the decrease in the dissolution rate of the granules (Shirley Junior; Meline, 1975; Timmons; Goertz, 1995).

The ability of controlling the release of $\mathrm{S}^{0}$ coated fertilizers can also be improved by the application of a polymer coating layer over the $\mathrm{S}^{0}$ layer (Goertz; Timmons; Mcvey, 1993; Hudson et al., 1995; Timmons; Goertz, 1995; Detrick 2002). Wax-based sealant are another option (Fersch; Stearns, 1977; Hudson et al., 1995; Hudson, 1999). The addition of plasticizers, such as polyethylene, polyurethane and polyvinyl acetate, together with $\mathrm{S}^{0}$ can improve the coating characteristics of the fertilizer (Watanabe et al., 2009; Azeem et al., 2014).

B esides the industrial processes, after the application to the soil, it is necessary the colonization of the $\mathrm{S}^{0}$ layer surface with micro-organisms able to degrade the coating. Degradation depends on the growth rate and on the activity of the microorganisms colonies, influenced by climatic and soil conditions of the cultivated area (Soaud et al., 2011).

A nother group is formed by the stabilized nitrogen fertilizers containing additives in their composition, which act as inhibitors of the urease enzyme and of the nitrification reaction. Urease inhibitors, such as NBPT, reduce the enzyme activity in the soil, and retain the $\mathrm{N}$ in the amide form for longer. In this context, it is possible to list some benefits related to the stabilization of urea with NBPT: late volatilization peak, which provides longer period of time for the incorporation of urea by the rainwater; reduction of volatilization losses due to excessive urea hydrolysis in the soil surface; increase of nitrogen uptake and of crop yield (Watson et al., 2008). Since NBPT reduces the conversion of urea to ammonium, it can be said that this molecule also indirectly influences nitrification due to the reduction of $\mathrm{NH}_{4}+$ ions concentration in the soil for nitrate convertion $\left(\mathrm{NO}_{3}^{-}\right)$. Fertilizers with nitrification inhibitors, such as DMPP (3,4 - dimethylpyrazole phosphate) and dicyanamide (DCD) $\left(\mathrm{H}_{4} \mathrm{C}_{2} \mathrm{~N}\right)$ act as microbicides, reducing the conversion of ammonium to nitrate in the soil (A zeem et al., 2014; Timilsena et al., 2014) and $\mathrm{N}$ losses by leaching and denitrification (Abalos et al., 2014; Ruser; Schukz, 2015; Alonso-Ayuso; Quemada, 2016).

Some studies carried out in different soil and climate conditions have shown benefits of stabilized and controlled release $\mathrm{N}$ urea when compared with conventional fertilizers, such as: a) increase of the yield and quality of the product; $b$ ) reduction of adverse effects of salinity on seed and seedlings; c) synchronization between the fertilizer nutrient release rate and the crop absorption curve; d) easiness of handling and storage; e) reduction in the use of hand labor, energy and machinery; f) reduction of nitrogen losses by volatilization, nitrous oxide emissions, and leaching (Abalos et al., 2014; Azeem et al., 2014; Timilsena et al., 2014; Geng et al., 2015; Naz; Sulaiman, 2016; Silva et at., 2017). 
In this scenario, the aspects related to the interaction of conventional, stabilized and and controlled release $\mathrm{N}$ fertilizers and the loss of ammonia and carbon dioxide are relevant for the management of $\mathrm{N}$ fertilization in $\mathrm{B}$ razil. The objective of this study was to quantify nitrogen losses by volatilization and $\mathrm{CO}_{2}$ emissions of conventional, stabilized and controlled release $\mathrm{N}$ fertilizers.

\section{MATERIAL AND METHODS}

\section{Characterization of the experimental area}

The experiment was carried out at the experimental area of the Technological Development Center of A griculture of the Federal University of Lavras, in Lavras, state of Minas Gerais (lat. $21^{\circ} 12^{\prime} 12.60^{\prime \prime} \mathrm{S}$; long. $46^{\circ} 58^{\prime} 41.73$ "W), from November 2013 to May 2014, without irrigation.

The region presents Cwb humid tropical climate with dry winter and temperate summer, according to the Köppen classification. The climate has two distinct seasons: dry season, from May to September; and rainy season, from October to April. The annual average temperature is $19.3{ }^{\circ} \mathrm{C}$, with average rainfall of 1.493 millimeters. Rainfall data, maximum and minimum temperature, and relative humidity were measured every day throughout the experiment by a climatological station.

The experimental area consisted of no-tillage system adopted for over 20 years with crop rotation: beans/soybean/corn., and bean was the previous crop to the implementation of the experiment. The soil of the experimental area was classified as dystrophic red latosol (Ferralsol in FAO's. For chemical and soil texture characterization, before the implementation of the experiment, soil samples were collected at $\mathrm{f} 0-0.05 ; 0-0.2$; and 0.21-0.40 $\mathrm{m}$ soil layers (Table 1).

\section{Experimental design}

The experimental consisted of a randomized block design with 11 treatments and three replications, totaling 33 plots. The experimental plot consisted of four $4 \mathrm{~m}$ rows in length, spaced $0.6 \mathrm{~m}$ apart. The useful area consisted of $3 \mathrm{~m}$ of the two central rows (both end rows were considered as border).

The treatments were: ten $\mathrm{N}$ fertilizers applied at a dose of $150 \mathrm{~kg} \mathrm{ha}^{-1} \mathrm{~N}$, in topdressing, and a control (without nitrogen): 1) Prilled urea; 2) Granular Urea; 3) Prilled urea incorporated at $0.02 \mathrm{~m}$ depth; 4) Ammonium sulfate; 5) Ammonium Nitrate; 6) Sulphurcoated urea (SCU) ; 7) Urea treated with $530 \mathrm{mg} \mathrm{kg}^{-1}$ of the molecule $\mathrm{N}$ - (n-butyl) thiophosphoric triamide (NBPT); 8) blend of urea $+\mathrm{S}^{0}+$ polymer (PSCU) and conventional granular urea; 9) Hydrolyzed Leather; 10) Urea + thermoplastic resin; 11) Control.

\section{Characterization of nitrogen fertilizers}

A mmonium sulfate: ammonium sulfate, conventional fertilizer containing $19 \% \mathrm{~N}$ and $22 \%$ $\mathrm{S}$, with additional supply of $174 \mathrm{~kg} \mathrm{ha}^{-1} \mathrm{~S}_{-} \mathrm{SO}_{4}^{-2}$. A mmonium nitrate: conventional fertilizer containing $30 \%$ N. Prilled urea: Conventional urea fertilizer $(46 \%$ $\mathrm{N})$. The term "prilled" is used to specify the finishing

Table 1: Chemical analysis and soil grading (1).

\begin{tabular}{|c|c|c|c|c|c|c|c|c|c|c|c|c|}
\hline Layer & $\mathrm{pH}$ & $\mathrm{P}\left(\right.$ Mehlich $\left.^{-1}\right)$ & $\mathrm{K}^{+}$ & $\mathrm{Ca}^{+2}$ & $\mathrm{Mg}^{+2}$ & $\mathrm{Al}^{+3}$ & $\mathrm{H}+\mathrm{Al}$ & SB & $(t)$ & $(\mathrm{T})$ & $\mathrm{V}$ & $\mathrm{m}$ \\
\hline$(\mathrm{m})$ & $\mathrm{H}_{2} \mathrm{O}$ & \multicolumn{2}{|c|}{$\mathrm{mg} \mathrm{dm^{-3 }}$} & \multicolumn{9}{|c|}{ - } \\
\hline $0-0.05$ & 5.7 & 25.3 & 134 & 4.0 & 1.3 & 0.1 & 4.4 & 5.6 & 5.7 & 10.0 & 56 & 1.7 \\
\hline $0-0.20$ & 5.2 & 6.2 & 60 & 1.8 & 0.5 & 0.4 & 6.3 & 2.5 & 2.9 & 8.8 & 29 & 13.7 \\
\hline $0.20-0.40$ & 5.2 & 2.9 & 46 & 1.5 & 0.4 & 0.3 & 5.1 & 1.9 & 2.2 & 7.0 & 28 & 13.5 \\
\hline Layer & O.M. & P-rem & $\mathrm{Zn}$ & $\mathrm{Fe}$ & $\mathrm{Mn}$ & B & \multicolumn{2}{|l|}{$S$} & Clay & Silt & \multicolumn{2}{|c|}{ Sand } \\
\hline$(\mathrm{m})$ & $\mathrm{g} \mathrm{kg}^{-1}$ & $\mathrm{mg} \mathrm{L}^{-1}$ & & \multicolumn{5}{|c|}{------------ mg dm³ } & \multicolumn{4}{|c|}{ 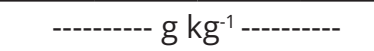 } \\
\hline $0-0.05$ & 36 & 16.3 & 9.3 & 37.0 & 36.0 & 0.3 & 13. & & 500 & 60 & & 440 \\
\hline $0-0.20$ & 36 & 14.2 & 2.5 & 34.2 & 34.6 & 0.2 & 31. & & 500 & 50 & & 450 \\
\hline $0.20-0.40$ & 26 & 13.3 & 2.1 & 31.6 & 33.7 & 0.1 & 26. & & 510 & 70 & & 420 \\
\hline
\end{tabular}

(1) Analytical determinations performed according to methodology proposed by CFSEMG (1999): $\mathrm{pH}_{\text {in }}$ water ratio (1:2,5) $\mathrm{Ca}^{2+}$, $\mathrm{Mg}^{2+}$, $\mathrm{Al}^{3+} \mathrm{KCl}$ extractor (1M); S (Monocalcium phosphate extractor in acetic acid); $\mathrm{P}, \mathrm{K}, \mathrm{Fe}, \mathrm{Zn}$ e Mn (Mehlich-1); H+ Al (Extractor SMP); Organic matter (OM) - Oxidation with $\mathrm{Na}_{2} \mathrm{Cr}_{2} \mathrm{O}_{7} 4 \mathrm{~N}+\mathrm{H}_{2} \mathrm{SO}_{4} 10 \mathrm{~N}$; $\mathrm{B}$ - Extractor: hot water.; Boron (Hot Water Extract); $\mathrm{SB}=\mathrm{Base}$ sum; $\mathrm{t}=\mathrm{CTC}$ effective; $\mathrm{T}$ = CTC potential; $\mathrm{V}$ = base saturation percentage; $\mathrm{m}$ = aluminum saturation; P-rem = remaining phosphorus. 
process of urea produced by solidification of the solution drops that fall in a prilled tower. Prilled urea presents mostly spherical-shaped particles, with diameter between 1 and 2 millimeters. The characterization by scanning electron microscopy (SEM) was carried out by Cancellier et al. (2016). Granular urea: conventional urea fertilizer $(45 \% \mathrm{~N})$. The term "granular" is used to specify the finishing process of the urea produced by agglomeration by means of physical or chemical process. Granular urea presents spherical-shaped particles, with diameter between 2 and 4 millimeters. Prilled urea incorporated at $0.02 \mathrm{~m}$ depth: conventional urea fertilizer $(45 \% \mathrm{~N})$. This treatment was used to demonstrate the effects of inadequate mechanical urea incorporation in soil at $0.002 \mathrm{~m}$ depth.

Coated urea $+\mathrm{S}^{0}:$ Granular U rea, conventional fertilizer, containing $37 \% \mathrm{~N}+16 \% \mathrm{~S}^{0}$, which promoted additional supply of $65 \mathrm{~kg} \mathrm{ha}^{-1} \mathrm{~S}-\mathrm{S}^{0} \mathrm{U}$ rea $+\mathrm{S}^{0}+$ Polymer: Physical Mixture of conventional granular urea (30\%), and $\mathrm{S}^{0}+$ polymer coated urea $(70 \%)$ containing $40 \%$ $\mathrm{N}+7.9 \%+\mathrm{S}^{0}$ polymers, which promoted additional supply of $30 \mathrm{~kg} \mathrm{ha-1} \mathrm{S}-\mathrm{S}^{0}$. Hydrolyzed leather: waste of the industrial processing of leather in granular form (Figure 1). Additional supply of $4 \mathrm{~kg} \mathrm{ha}^{-1} \mathrm{~S}$ (Table 2). Urea + NBPT: Granular Urea, conventional fertilizer, containing $45 \% \mathrm{~N}$ and treated with $530 \mathrm{mg} \mathrm{kg}^{-1} \mathrm{NBPT}$ with the function of acting as inhibitor of urease in the soil. Urea + thermoplastic resin $(44 \% \mathrm{~N})$ : granular urea, conventional fertilizer, containing $23.84 \mu \mathrm{m}$ thick polyurethane coating, with the function of reducing the hygroscopicity of the fertilizer and the $\mathrm{N}$ diffusion (Figure 2e).

A fter choosing the $\mathrm{N}$ fertilizers for the agronomic eval uation in corn crops, some of them (urea +thermoplastic resin, hydrolyzed leather, and urea $\left.+16 \% \mathrm{~S}^{0}\right)$ were selected for the characterization by SEM and energy dispersive $\mathrm{X}$-ray spectrometry (EDS); (Figures 1, 2 and 3). The analysis was carried out in the Laboratory of Electron Microscopy and Ultra-Structure Analysis (LME), of the Department of Plant Pathology (DFP), UFLA. Fertilizers samples were divided into four parts, and the selected granules were cut using a scalpel; samples were set in "stubs", metallized in a carbon evaporator device model Union CED 020, and observed in in the Scanning Electron Microscope model LEO EVO 40 XVP Zeiss. Samples were qualified, quantified, and mapped regarding the chemical composition by Spectroscopy Energy Dispersive X-Ray using the Quanta X Flash 5010 B ruker device, according to the methodology described by Cancellier et al. (2016).
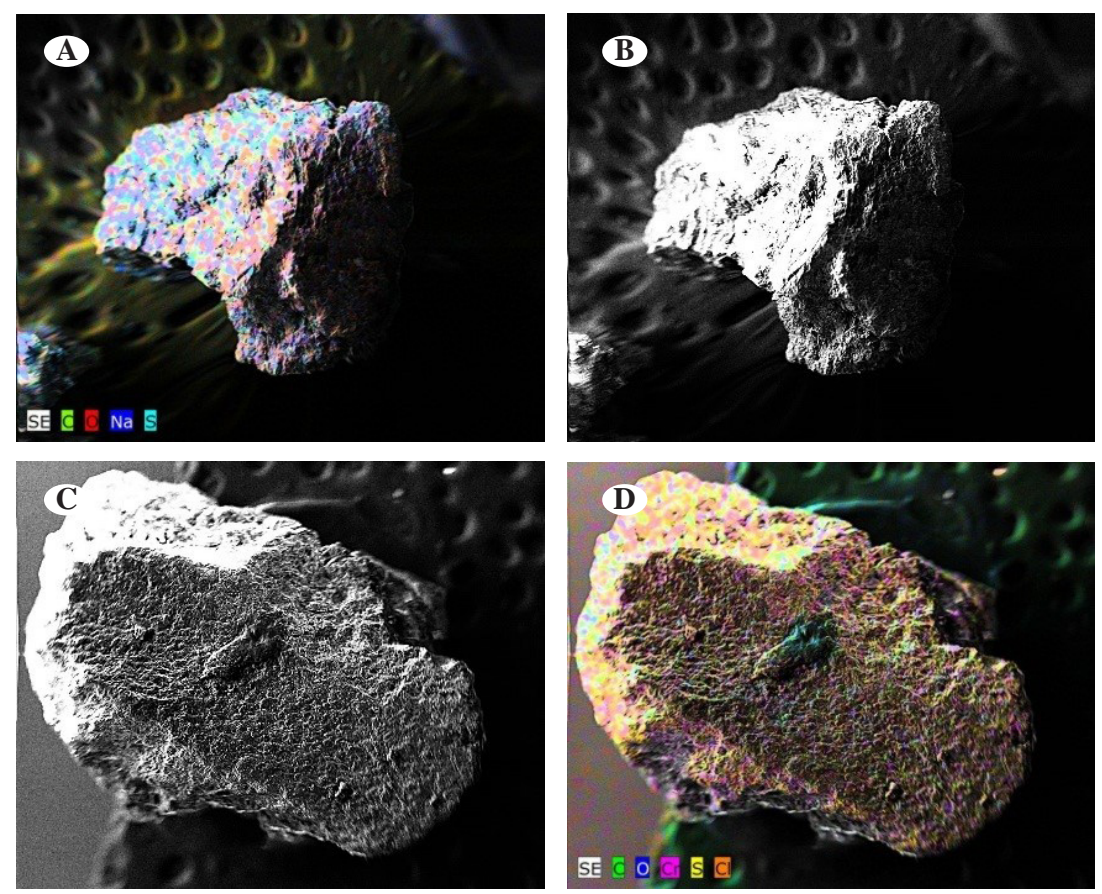

Figure 1: Scanning electrochemography of leather hydrolyzate (A); EDS mapping of carbon, oxygen, sodium and sulfur (B); leather hydrolyzate (C); EDS mapping of carbon, oxygen, chromium, sulfur and chlorine (D). 
Table 2: Chemical characteristics of the leather hydrolyzate.

\begin{tabular}{|c|c|c|c|}
\hline Characteristics & Unit & Dry base $-110^{\circ} \mathrm{C}$ & Natural humidity \\
\hline $\mathrm{pH} \mathrm{CaCl}{ }_{2}^{(1)}$ & - & - & 3.62 \\
\hline Density & $\mathrm{g} \mathrm{cm}^{-3}$ & - & 0.62 \\
\hline Total humidity & $\%$ & - & 5.5 \\
\hline Total Nitrogen & $\%$ & 13.07 & 12.35 \\
\hline Organic material(2) $^{(2)}$ & $\%$ & 67.34 & 63.64 \\
\hline Total carbon(3) & $\%$ & 37.41 & 35.36 \\
\hline Organic carbon & $\%$ & 32.53 & 30.74 \\
\hline Mineral residue ${ }^{(4)}$ & $\%$ & 33.14 & 31.32 \\
\hline C/N Ratio(5) & - & $3 / 1$ & - \\
\hline C/N Ratio(6) & - & $2 / 1$ & - \\
\hline P2O5 & $\%$ & 0.07 & 0.07 \\
\hline $\mathrm{K} 2 \mathrm{O}$ & $\%$ & 0.07 & 0.07 \\
\hline Calcium & $\%$ & 0.1 & 0.09 \\
\hline Magnesium & $\%$ & 0.01 & 0.01 \\
\hline Sulfur & $\%$ & 0.36 & 0.34 \\
\hline Boron & $\mathrm{mg} \mathrm{kg}^{-1}$ & 1 & 1 \\
\hline Iron & $\mathrm{mg} \mathrm{kg}^{-1}$ & 37 & 35 \\
\hline Zinc & $\mathrm{mg} \mathrm{kg}^{-1}$ & 1 & 1 \\
\hline CTC & $\mathrm{cmolc} \mathrm{kg}^{-1}$ & 32 & 30 \\
\hline Chrome & $\%$ & 0.23 & - \\
\hline
\end{tabular}

Official MAPA methodology: (1) Relation 1: 2,5; (2) Total (Combustion; (3) Organic and mineral; (4) Total; (5) Carbon and total nitrogen, (6) Organic carbon and total nitrogen.

\section{Sowing and cultivation}

For corn sowing, it was used the simple hybrid DKB $390 \mathrm{VTPRO}^{\circledR}$. Sowing and maintenance fertilization were carried out mechanically on N ovember $15^{\text {th }}, 2013$. The spacing between the line was of $0.6 \mathrm{~m}$, with final stand of 77,089 plants $\mathrm{ha}^{-1}$. Fertilization at sowing was based on soil analysis. It was applied $429 \mathrm{~kg} \mathrm{ha}^{-1}$ of the mixed mineral fertilizer: 08-28-16 $+1.6 \% \mathrm{Ca}+2.1 \% \mathrm{~S}+0.05 \% \mathrm{~B}+0.06 \% \mathrm{Mn}+0.27 \% \mathrm{Zn}$.

When the plants presented five fully expanded leaves (V5 stage), at 28 days after sowing (November $15^{\text {th }}, 2013$ ), topdressing was carried out with $\mathrm{N}$ fertilizer (treatments). The fertilizers were distributed manually in strips, and at a distance of $0.10 \mathrm{~m}$ from the stalk of corn plants without plot at doses of $150 \mathrm{~kg} \mathrm{ha}^{-1} \mathrm{~N}$ (treatments), and $120 \mathrm{~kg} \mathrm{ha}^{-1}$ $\mathrm{K}_{2} \mathrm{O}$ (potassium chloride with $58 \% \mathrm{~K}_{2} \mathrm{O}$ ).

\section{Ammonia volatilization $\left(\mathrm{N}-\mathrm{NH}_{3}\right)$}

For quantification of ammonia volatilization, it was used the semi-open collector method, adapted by L ara
Cabezas (1999). It was used fixed bases for the rotation of the chambers at each eval uation. The chambers were made with white PVC tubes ( $0.20 \mathrm{~m}$ diameter, $0.50 \mathrm{~m}$ height). The chambers were coupled at $0.05 \mathrm{~m}$ height to another PVC pipe (base) $(0.20 \mathrm{~m}$ diameter; $0.15 \mathrm{~m}$ height). The base was inserted into the soil at $0.10 \mathrm{~m}$ depth between rows, at a distance of $0.10 \mathrm{~m}$ from the corn sowing rows, spaced $0.50 \mathrm{~m}$ apart, with three replications per plot.

For the volatilized ammonia collection, two disks of laminated sponge with a density of $0.02 \mathrm{~g} \mathrm{~cm}^{-3}$ and 2.5 $\mathrm{cm}$ of thickness were used. The sponges were soaked with $80 \mathrm{~mL}$ phosphoric acid solution $\left(\mathrm{H}_{3} \mathrm{PO}_{4}\right)$ and glycerin in $60 \mathrm{ml} \mathrm{L}^{-1}$ and $50 \mathrm{ml} \mathrm{L}^{-1}$ volumes. Later, they were fixed to the heights of 25 and $45 \mathrm{~cm}$ of the soil. The sponge at the height of $45 \mathrm{~cm}$ has the function of avoiding contamination of the lower sponge and for this reason has not been evaluated. The lower sponge (height $25 \mathrm{~cm}$ ) was used to quantify the volatilized ammonia.

The solution of the sponges collected in the field were extracted by filtration in a Büchner funnel with 
the aid of a vacuum pump, after 5 washes in sequential extractions with $80 \mathrm{~mL}$ of deionized water each. From the extract, aliquots were taken to determine the $\mathrm{N}$ content by distillation by the K jedahl method.

The daily ammoniavol atilization was determined at $1,2,3,4,5,7,10,14,17,22,27,32,38,46$ and 55 days after $\mathrm{N}$ fertilization in topdressing.

\section{Daily flows and total $\mathrm{C}-\mathrm{CO}_{2}$ emissions}

The quantification of the $\mathrm{CO}_{2}$ daily flows was carried out after the application of $\mathrm{N}$ fertilizers in topdressing from N ovember $15^{\text {th }}, 2013$ to January $14^{\text {th }}, 2014$.
The dynamic chambers consisted of a closed system in which the PVC pipe with $0.10 \mathrm{~m}$ in diameter were inserted into the soil at $0.03 \mathrm{~m}$ depth, at a distance of 0.15 $\mathrm{m}$ from the corn sowing row in each treatment. The rings were inserted after the emergence of corn plants.

For quantification of the daily $\mathrm{CO}_{2}$ flows, it was used the LICOR-8100 a device (LICOR Inc., Lincoln, $\mathrm{NE})$. The $\mathrm{CO}_{2}$ flow in the chamber was quantified for 2 minutes in each plot. The readings were carried out at the same time every day, from 8 a.m to 10 a.m, in order to reduce the interference of the ambient temperature on the $\mathrm{CO}_{2}$ flow emitted by the fertilizers.
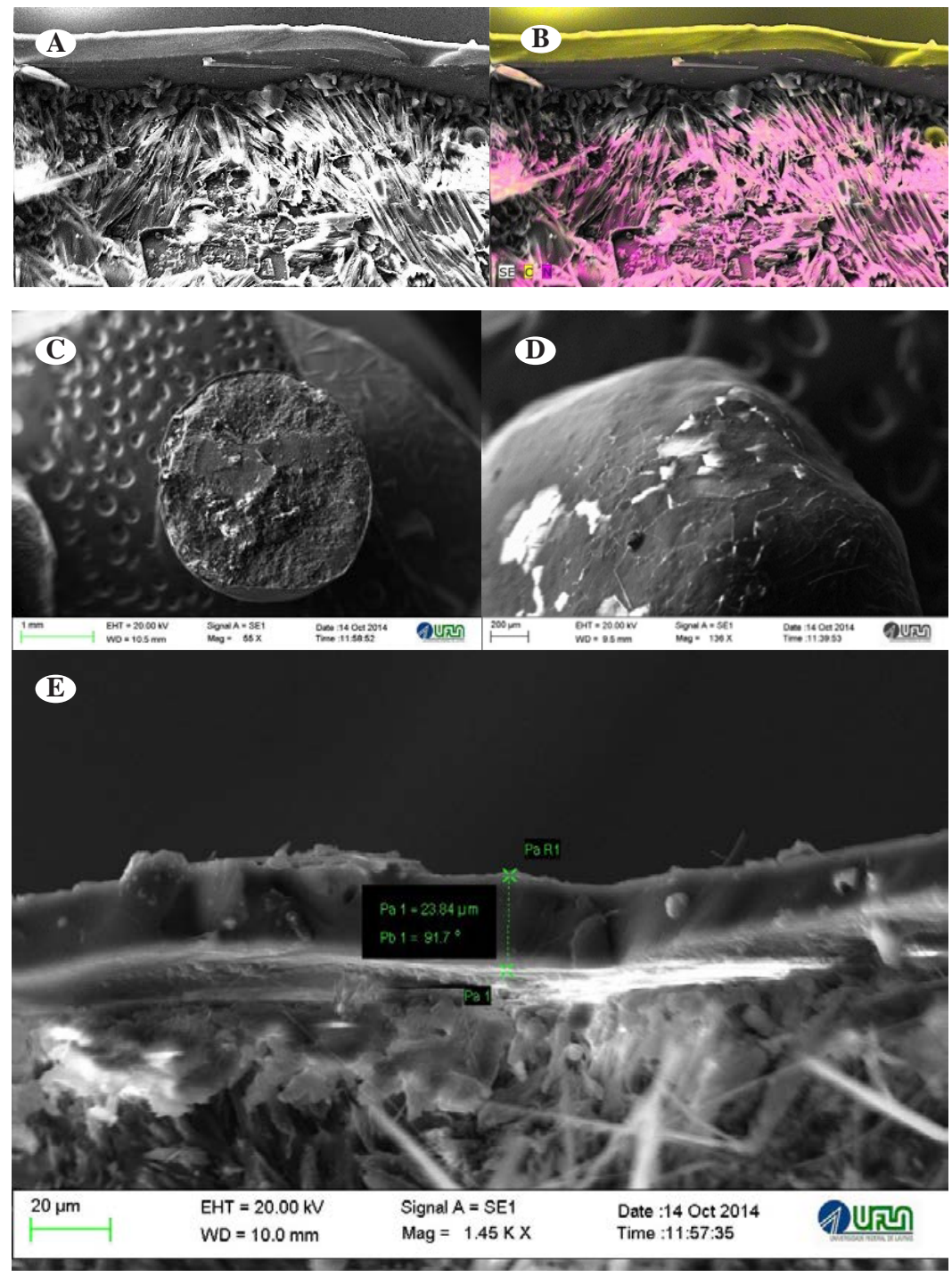

Figure 2: Scanning electromyrography of urea coated with thermoplastic resin. Urea coated with thermoplastic resin (A); EDS mapping of carbon and nitrogen (B); general appearance of the granule and coating (C); external appearance of the urea coating with thermoplastic resin (D); coating thickness equal to $23.84 \mu \mathrm{m}(\mathrm{E})$. 

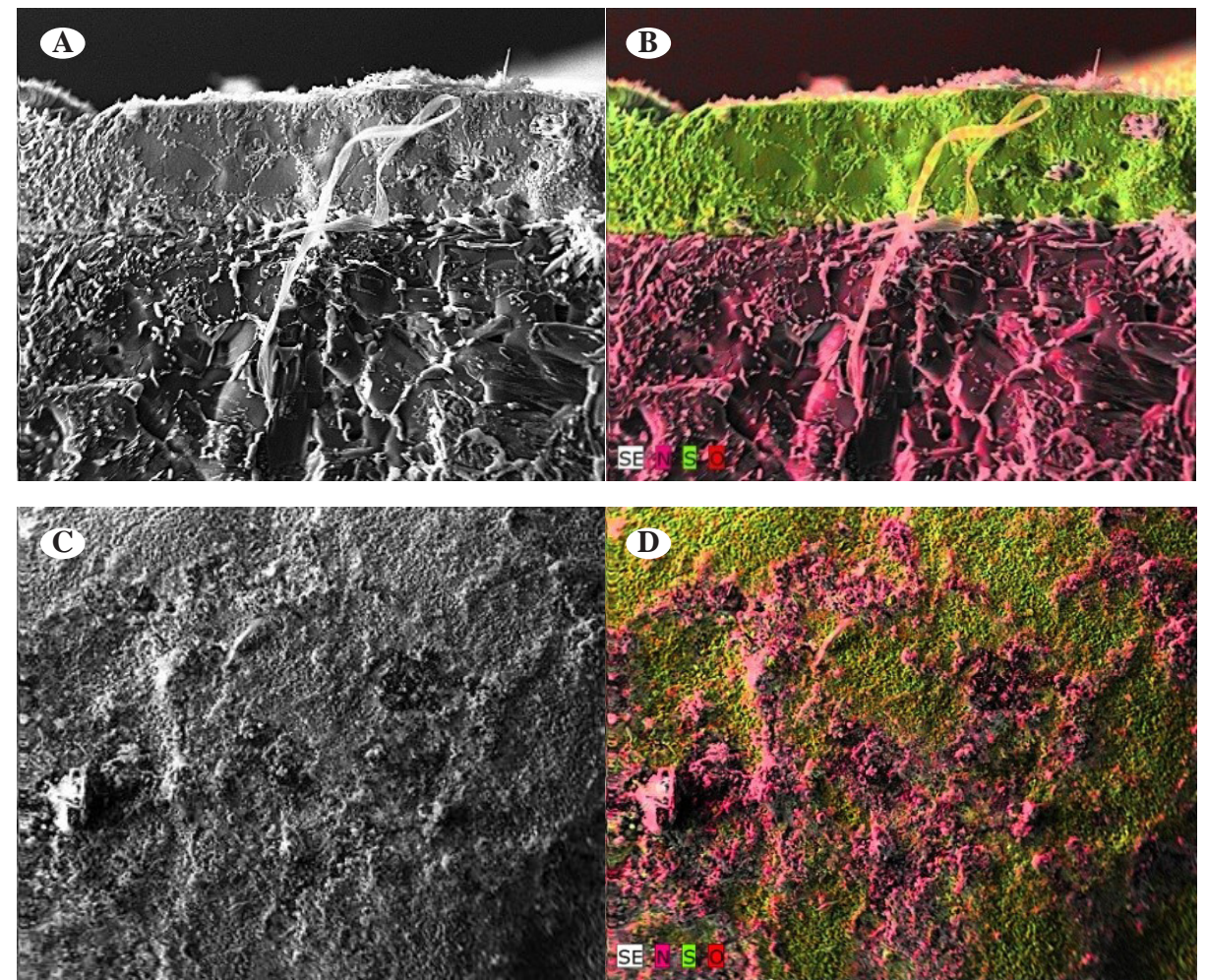

Figure 3: Scanning electromyography of urea coated with $16 \%$ elemental sulfur $\left(\mathrm{S}^{\circ}\right)$. Urea coated with $16 \%$ elemental sulfur (A); EDS mapping of nitrogen, sulfur and oxygen, external coating $\left(\mathrm{S}^{0}\right)(\mathrm{B})$; general appearance of the granule and coating (C); EDS mapping of nitrogen, sulfur and oxygen from the external surface of the fertilizer granule (D).

Quantification of $\mathrm{CO}_{2}$ flows was carried out one day before (0), and on the $1^{\text {st }}, 2^{\text {nd }}, 3^{\text {rd }}, 4^{\text {th }}, 5^{\text {th }}, 7^{\text {th }}, 10^{\text {th }}, 14^{\text {th }}$, $17^{\text {th }}, 22^{\text {nd }}, 27^{\text {th }}$ and $32^{\text {nd }}$ day after the application of nitrogen fertilizers in topdressing.

The daily data, expressed in $\mu \mathrm{mol} \mathrm{m}^{-2} \mathrm{~s}^{-1} \mathrm{CO}_{2}$ were converted to $\mathrm{kg} \mathrm{ha}^{-1} \mathrm{~d}^{-1}$. Subsequently the total $\mathrm{CO}_{2}$ emissions was calculated for 32 days (A)-K aisi et al., 2008):

Total $\mathrm{CO}_{2}$ emission $(\mathrm{t})=\sum_{\mathrm{i}}^{\mathrm{n}} \frac{X_{i}+X_{i+1}}{2} \cdot\left(\mathrm{t}_{\mathrm{i}+1}-\mathrm{t}\right)$

In which: $X_{i}$ is the $1^{\text {st }}$ day of $\mathrm{CO}_{2}$ quantification, and $X_{i+1}$ is the following days at the times $t_{i}$ and $t_{i+1}$, respectively; $n$ is the final period of $\mathrm{CO}_{2}$ quantization in the study period. For the adjacent samplings dates, it was carried out the calculation by means of interpolation.

\section{Statistical analysis}

Data were subjected to analysis of variance (ANOVA) and the means were compared by the Skott Knott test $(\mathrm{a}=0.05)$. ANOVA was carried out after verifying the normality (Shapiro-Wilk's test) and homogeneity of variance (Bartlett's test) of the data. Statistical analyses were carried out using the statistical analysis software SISVAR 5.3 ${ }^{\circledR}$ (Ferreira, 2011).

\section{RESULTS AND DISCUSSION}

\section{Daily and cumulative $\mathrm{N}-\mathrm{NH}_{3}$ losses}

Figures $4 \mathrm{~A}$ and $4 \mathrm{~B}$ show the variations in the daily ammonia volatilization $\left(\mathrm{N}-\mathrm{NH}_{3}\right)$, the rainfall, the temperature, and the relative humidity after the application of $\mathrm{N}$ fertilizer.

The intensity of the daily $\mathrm{N}-\mathrm{NH}_{3}$ loss is influenced by factors related to soil and climate of corn crop area, such as temperature and soil moisture, relative humidity, wind speed, rainfall, cation exchange capacity (CEC), soil acidity buffer power $(\mathrm{H}+\mathrm{Al})$, organic matter $(\mathrm{OM}), \mathrm{N}$ source and urease activity (Watson et al., 2008). In addition to these factors, the $\mathrm{N}-\mathrm{NH}_{3}$ loss is directly related to the $\mathrm{pH}$ close 


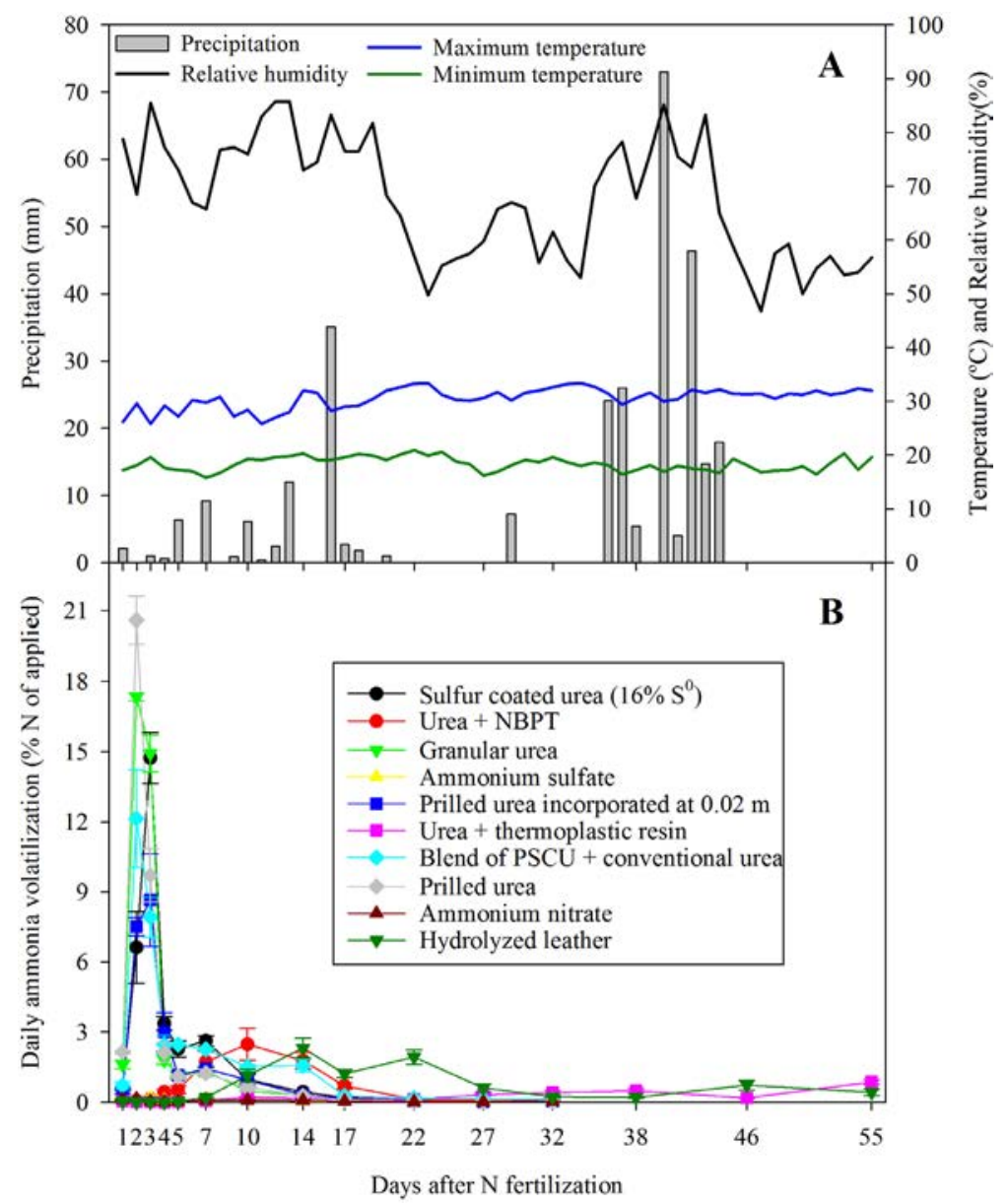

Figure 4: Climatic data (A) and daily ammonia volatilization (B) 55 days after $\mathrm{N}$ fertilization with conventional stabilized and controlled fertilizers in summer corn crop. The vertical bars represent the standard error of the means $(n=3)$.

to the granules (dissolution region), which determines the ratio between $\mathrm{NH}_{3}$ and $\mathrm{NH}_{4}{ }_{4}^{+}$in the soil solution (Cantarella; Nitrogênio; Novais, 2007). In this study, $\mathrm{pH}$ values (water), effective CEC, soil acidity buffer power $(\mathrm{H}+\mathrm{Al})$, and organic matter in the soil layer of 0 to $0.05 \mathrm{~m}$ were: $5.7 ; 5.7$ $\mathrm{cmol}_{\mathrm{c}} \mathrm{dm}^{-3} ; 4.4 \mathrm{cmol}_{\mathrm{c}} \mathrm{dm}^{-3}$, and $36 \mathrm{~g} \mathrm{~kg}^{-1}$ (Table 1 ), which is the soil region that influences the intensity of $\mathrm{N}-\mathrm{NH}_{3}$ losses of the $\mathrm{N}$ fertilizer applied. Climatic data show that the total rainfall in the first 30 days after $\mathrm{N}$ fertilizers application was of $89 \mathrm{~mm}$, with two millimeters $(\mathrm{mm})$ on the day of the $\mathrm{N}$ fertilizer in topdressing (N ovember $15^{\text {th }}, 2013$ ) and $0 ; 1 ; 1 ; 6 ; 9$; and $0 \mathrm{~mm}$ between the $2^{\text {nd }}$ and $8^{\text {th }}$ day after, with average temperature of $23{ }^{\circ} \mathrm{C}$ (Figure 4a).

The daily $\mathrm{N}-\mathrm{NH}_{3}$ losses were influenced significantly $(\mathrm{p} \leq 0.05)$ by conventional, stabilized and controlled release $\mathrm{N}$ fertilizers applied in in corn crops
(Figure 4b). All the stabilized and controlled release $\mathrm{N}$ fertilizers reduced the peaks of daily $\mathrm{N}-\mathrm{NH}_{3}$ losses in comparison with prilled or granular urea.

The critical relative humidity of urea (fertilizer) is $74.3 \%$ at $30{ }^{\circ} \mathrm{C}$, i.e.. So, when the air relative humidity is higher than $74.3 \%$, urea absorbs water from the air in atmosphere, which characterizes the beginning of the dissolution process of the urea granules. In this study, the values of relative air humidity were higher than $74.3 \%$ on the $1^{\text {st }}$ and $3^{\text {rd }}$ day after the application of $\mathrm{N}$ fertilizers, which allows the occurrence of ammonia volatilization peaks in the first 3 days: granular urea ( $20.6 \%$ of $\mathrm{N}$ applied), prilled urea $(17.3 \% \mathrm{~N})$, and blend of PSCU and conventional urea $(12.1 \% \mathrm{~N})$, which occurred on the $2^{\text {nd }}$ day. For the sulfur coated urea coated and for prilled urea incorporated at $0.02 \mathrm{~m}$ depth, the maximum daily $\mathrm{N}-\mathrm{NH}_{3}$ loss was on the 
$3^{\text {rd }}$ day after fertilization, with values of 14.7 and $8.7 \% \mathrm{~N}$, respectively. Thus, relative humidity above $75 \%$ contributed to the rapid dissolution of urea (granular, prilled) in the soil, and to the occurrence of volatilization peak until the first three days after the application of nitrogen fertilizers. Depending on the soil and climatic conditions of the area, only the dew is enough to start the process of dissolution of urea granules (Cantarella; Nitrogênio; Novais, 2007).

Urea coated with $16 \% \mathrm{~S}^{0}$ isolated, i.e., with no other coating layer of hydrophobic materials, which reduce cracks and porosity of the $\mathrm{S}^{0}$ layer (Figure 3 ), was not enough to prevent rapid water passage, dissolution, and urea diffusion from the granules to the soil solution. Thus the $\mathrm{N}$ derivative from urea coated with $16 \% \mathrm{~S}^{0}$ remained subjected to volatilization losses immediately after the application of the coating, although they occurred later, and in a lower value, when compared with conventional urea without coating.

The mechanism of nutrient release of urea coated with $\mathrm{S}^{0}$ has been the subject of several studies ( $\mathrm{L} i$ et al., 2008; Wu; Liu, 2008; Trenkel, 2010; Davidson; Gu, 2012; Timilsena et al., 2014). However, it is now accepted the theory that coated urea allows the release of $\mathrm{N}$ in the amide form through the pores and cracks that appear in the $\mathrm{S}^{0}$ layer after contact with water (Azeem et al., 2014).

Two of the fertilizers used in this study represent the coating technologies of urea with Sulphur: urea coated with $16 \% \mathrm{~S}^{0}$, without sealant (Figure 3), and urea coated with $7.9 \% \mathrm{~S}^{0}$ + polymers (with sealant), which is an organic polymer. As illustrated in Figures $3 \mathrm{a}, 3 \mathrm{~b}$ and $3 \mathrm{c}$, it is observed that urea coated with $16 \%$ $\mathrm{S}^{0}$ presented no cracks. Similar evaluation was carried out by Cancellier et al. (2016) with urea coated with $7.9 \% \mathrm{~S}^{0}+$ polymers. The difference between the two types of coatings is that the additional layer of polymers serves as water passage control and as dissolution of the urea present innner granules. Thus, the thickness of the coating determines the $\mathrm{N}$ release rate of the fertilizer, which can be established in function of the $\mathrm{N}$ absorption curve of the crop. Furthermore, the soil temperature and the moisture are factors that control the nitrogen release of the fertilizer, since the coating is porous, i.e., as the temperature increases, the granule expands, allowing water inlet and outlet through the coating (Azeem et al., 2014; Naz; Sulaiman, 2016).

A nother relevant factor for sulfur coated urea is the difference between the time required for the generation of acidity due the conversion of $\mathrm{S}^{0}$ into sulfate $\left(2 \mathrm{~S}^{0}+3 \mathrm{O}_{2}+2\right.$ $\mathrm{H}_{2} \mathrm{O} \rightarrow 2 \mathrm{H}_{2} \mathrm{SO}_{4} \rightarrow 4 \mathrm{H}^{+}+1 \mathrm{SO}_{4}^{-2}$ ) and the urea hydrolysis may not allow the $\mathrm{pH}$ buffering around the granule.
The incorporation of urea at $0.02 \mathrm{~m}$ depth promoted reduction of its peak of $\mathrm{N}-\mathrm{NH}_{3}$ volatilization $(8.6 \%$ of the applied $\mathrm{N}$ ), which is lower than the half, when compared with the prilled $(20.6 \%$ of the applied $\mathrm{N})$ or granular urea $(17.3 \%$ of the applied $\mathrm{N}$ ) applied to the surface. $\mathrm{N}-\mathrm{NH}_{3}$ losses are higher when urea is applied to the surface, i.e., without mechanical incorporation, or by the rain and/or irrigation water (Rochette et al., 2009). This is due to diffusion resistance of the ammonia present in the liquid and gas phase in the soil. The diffusion coefficient of nitrate and ammonium ions present values of $10^{-6}$ and $10^{-7} \mathrm{~cm}^{2} \mathrm{~s}^{-1}$ (Watanabe et al., 2009).

The incorporation of urea at $0.075 \mathrm{~m}$ depth promoted $\mathrm{N}-\mathrm{NH}_{3}$ losses lower than $10 \%$ of the applied N (Rochette et al., 2014). Therefore, the incorporation of urea at depth is sufficient to control N-NH $\mathrm{N}_{3}$ losses (Fontoura; Bayer, 2010).

The application of urea treated with $530 \mathrm{mg} \mathrm{kg}^{-1}$ NBPT promoted the reduction and delay in daily $\mathrm{N}_{-} \mathrm{NH}_{3}$ losses which started to increase from the $5^{\text {th }}$ day after yours application, with a maximum value of $2.5 \%$ of the $\mathrm{N}$ applied, which occurred 10 days after its application to the soil surface.

In a study carried out by Cancellier et al. (2016)the largest daily $\mathrm{N}-\mathrm{NH}_{3}$ loss of the urea occurred on the $2^{\text {nd }}$ day after fertilization, and was $12 \%$ of total $\mathrm{N}$ applied in topdressing. Blend of PSCU and urea (5.6\% of the applied $\mathrm{N})$ and urea treated with NBPT ( $7 \%$ of the applied N) promoted daily peaks of $\mathrm{N}-\mathrm{NH}_{3}$ emission on the $3^{\text {rd }}$ and $4^{\text {th }}$ day after its application to the soil surface, respectively.

Thus, the intensity and the delay (10 days) in the daily N-N $\mathrm{H}_{3}$ loss of the urea treated with NBPT also depend on soil and climate factors, but with less intensity when compared with conventional urea (granular or prilled).

The maintenance of the urea in amide form $\left(\mathrm{N}-\mathrm{NH}_{2}\right)$ in the soil for five days from the day of the topdressing, due to the action of the NBPT, was sufficient for the occurrence of $10 \mathrm{~mm}$ rainfall. This rainfall, summed to the total rainfall of the four previous days ( $11 \mathrm{~mm}$ ), promoted the incorporation of urea into the soil, and the reduction in cumulative loss of $\mathrm{N}-\mathrm{NH}_{3}$ of the urea treated with $530 \mathrm{mg} \mathrm{kg}^{-1}$ NBPT (Figure 4a).

Dawar et al. (2011) quantified the distance of lateral and vertical movement of urea + NBPT applied to the surface (100 kg ha-1), under controlled conditions, after $8 \mathrm{~mm}$ irrigation. The authors reported that, in addition to reducing the urea hydrolysis rate, NBPT increases its vertical and lateral movement in the soil. This is because the $\mathrm{N}$ remains longer in the amide form [( $\left.\left.\left(\mathrm{NH}_{2}\right)_{2} \mathrm{CO}\right)\right]$, and since the urea molecule does not have negative charges on the surface, its horizontal distribution in the soil profile is easier. On the other hand, ammonium $\left(\mathrm{NH}_{4}^{+}\right)$is attracted by electrostatic forces to the negative charges present on the surface of the organic 
matter and of the mineral fraction of the soil solid phase, and has lower coefficient of diffusion in the soil $\left(1.00 \times 10^{-7}\right.$ $\left.\mathrm{cm}^{2} \mathrm{~s}^{-1}\right)$, when compared with that of urea $\left(1,18 \times 10^{-5} \mathrm{~cm}^{2} \mathrm{~s}^{-1}\right)$.

A irrigation water $(11.4 \mathrm{~mm}$ )applied by center pivot system was sufficient to incorporate urea and reduce $\mathrm{N}-\mathrm{NH}_{3}$ losses to $5.5 \%$ of the $\mathrm{N}$ applied to wheat crops in sandy soil. On the other hand, in non-irrigated area, the $\mathrm{N}-\mathrm{NH}_{3}$ loss by volatilization reached a mean value of $60 \%$ of the $\mathrm{N}$ applied to wheat crops (H olcomb et al., 2011).

A mmonium nitrate and sulfate, urea coated with thermoplastic resin, and hydrolyzed leather did not promote daily peaks of $\mathrm{N}-\mathrm{NH}_{3}$ loss.

On the $14^{\text {th }}$ day, ammonia loss from hydrolyzed leather was $2.3 \%$ of $\mathrm{N}$ applied. The days with heaviest rainfall occurred in the period between the $10^{\text {th }}$ and the $20^{\text {th }}$ day after the topdressing (Figure 4a), and coincided with the higher volatilization of the $\mathrm{N}-\mathrm{NH}_{3}$ of the hydrolyzed leather. Due to the increase in soil moisture, caused by the rain, and to the high temperature $\left(32{ }^{\circ} \mathrm{C}\right)$ on the $14^{\text {th }}$ day after fertilization, there was appropriate conditions (Cantarella; Nitrogênio; Novais, 2007) for the occurrence of $\mathrm{N}$ mineralization of the hydrolyzed leather that was subjected to losses. Thus, hydrolyzed leather promotes $\mathrm{N}$ release as function of the mineralization rate, which is affected by the soil and climate conditions (Figure 4a) and the $\mathrm{C} / \mathrm{N}$ ratio (Cantarella; Nitrogênio; Novais, 2007), which is $3 / 1$ (low), showing potential of immediate mineralization of the organic $\mathrm{N}$ (Table 2).

Cumulative $\mathrm{N}_{-} \mathrm{NH}_{3}$ loss by conventional, stabilized and controlled release $\mathrm{N}$ fertilizer, during 55 days, in descending order was: Granular Urea $(39 \%$ of the N applied $)=$ prilled urea $(38 \%)>$ urea $+16 \% \mathrm{~S}^{0}(32 \%)=$ blend of PSCU and urea $(32 \%)>$ incorporated prilled urea $(24 \%)>$ urea + NBPT $(8 \%)=$ hydrolyzed leather $(9 \%)>$ urea + thermoplastic resin $(3 \%)=$ ammonium sulphate $(1 \%)=$ ammonium nitrate $(0.7 \%)$ (Figure 5$)$.

The cumulative loss of $\mathrm{N}-\mathrm{NH}_{3}$ with the application of urea $+530 \mathrm{mg} \mathrm{kg}^{-1} \mathrm{NBPT}$ was $8.3 \%$ of the $\mathrm{N}$ applied, which is significant reduction $\left(79 \%\right.$ of $\left.\mathrm{N}-\mathrm{NH}_{3}\right)$ when compared with granular urea applied to the soil surface. The addition of NBPT to urea also promoted reduction of $\mathrm{N}-\mathrm{NH}_{3}$ losses from $15 \%$ to $78 \%$, when compared with conventional urea in experiments carried out at different locations with sugarcane (Cantarella et al., 2008).In summer corn crop area located in South om Minas Gerais state the percentage of reduction in $\mathrm{N}-\mathrm{NH}_{3}$ loss of urea + NBPT in comparison with urea was $18.6 \%$ of the $\mathrm{N}$ applied in topdressing. The cumulative $\mathrm{N}-\mathrm{NH}_{3}$ loss was $25.4 \%$ of the $\mathrm{N}$ applied in the form of urea treated with NBPT, and applied to the surface (Cancellier et al., 2016).

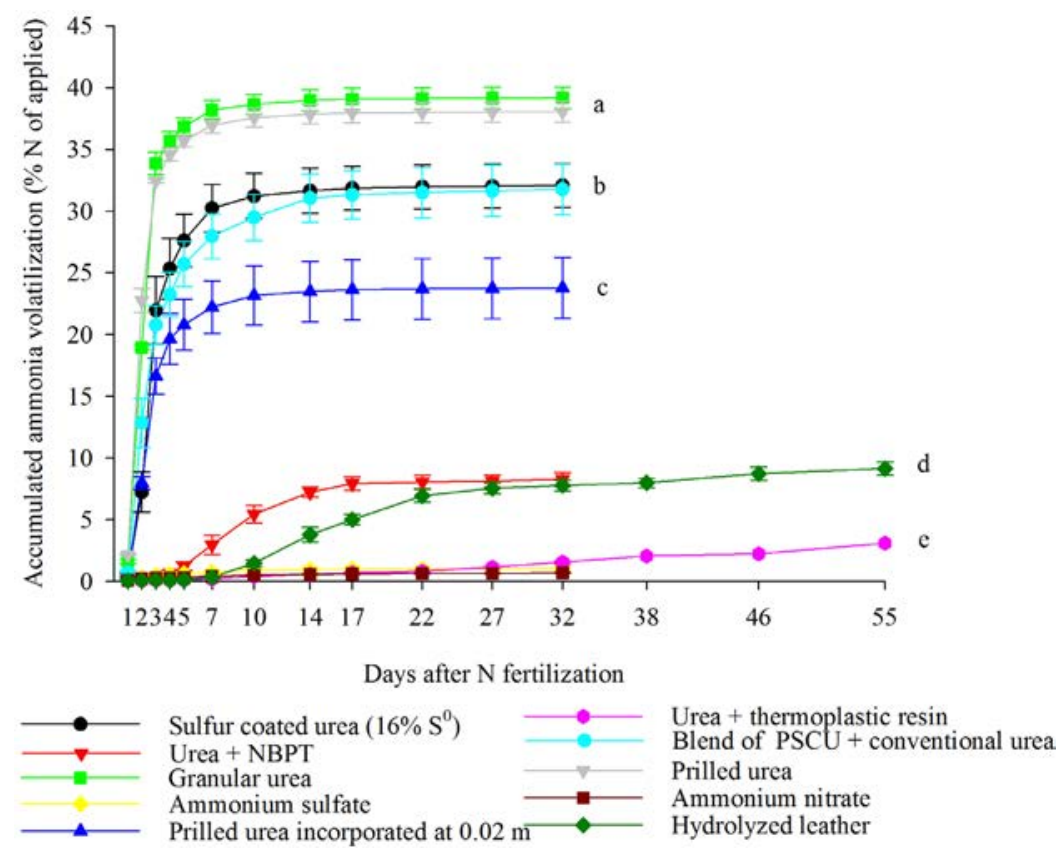

Figure 5: Cumulating $\mathrm{N}-\mathrm{NH}_{3}$ losses by volatilization, after 55 days after the application of conventional, stabilized and controlled $\mathrm{N}$ fertilizers in summer corn crop. Treatments grouped by the same letter do not differ from each other by the Skott-Knott test at 5\% significance. The vertical bars represent the standard error of the means $(n=3)$. 
Results obtained by Cantarella et al. (2008) showed that cumulative $\mathrm{N}-\mathrm{NH}_{3}$ losses of urea + NBPT were 7.2; $15.2 ; 21.3 ; 1.6 ; 13.4 ; 0.8$ and $11.2 \%$ of the $\mathrm{N}$ applied to different locations and application times. Several studies have shown that the application of urea stabilized with urease inhibitors, such as NBPT, is associated with the reduction, at different intensities, in $\mathrm{N}-\mathrm{NH}_{3}$ loss by volatilization (Rawluk et al., 2001; Cantarella et al., 2008; Watson et al., 2008; Pereira et al., 2009; Grohs et al., 2011; Silva et al., 2016).

The conversion of NBPT to its analog NBPTO, which is a molecule with the ability of reducing the urease activity in the soil has been the most used explanation to clarify the delay in the conversion of urea to ammonia in the soil, and in the intensity and reduction in volatilization peaks (Creason; Schmitt; Hendrickson, 1990; Byrnes; Freney, 1995; Phongpan et al., 1995; Watson, 2008). The chemical basis proposed (Manuza et al., 1999; Dominguez et al., 2008; Font et al., 2008) for the mechanism of inhibition of urease activity by the NBPT $(\mathrm{O})$ is based on the following chemical principles: 1) the NBPT molecule (O) coordinates with nickel atoms $(\mathrm{Ni})$ of the urease (active site of the enzyme) in a bidentate geometry (each $\mathrm{Ni}$ atom is bonded in two points on NBPT molecule); 2) The oxygen and the amide of the NBPT are present in the bonds formed between the Ni atoms; 3 ) The other amino group of the NBPT molecule forms a hydrogen bond with the oxygen of the carbamate; These are the chemistry explanation for the reason why it is necessary to convert NBPT (S) to its analog NBPT $(\mathrm{O})$ : the urease inhibition efficiency is related to the presence of the oxygen atom instead of the sulfur in the NBPT molecule; 4) The stability of the bidentate complex bond is stronger than the hydrogen bond; 5) Thus, the molecule inhibitor binds to the active site of the urease enzyme in three points (tridentate bond); 6) Consequently, the possibility of urea to react with $\mathrm{Ni}$ atoms of the enzyme urease is reduced when the active site is blocked by the NBPT $(\mathrm{O})$.

Another important factor is that NBPT is sensitive to high temperature and humidity (Engel; Jones; Wallander, 2013). Typically, this compound is mixed with solvents, such as glycols or derivatives, and is subsequently homogeneously distributed to urea (Sutton; Thornsberry, 2013; Whitehurst; Whitehurst, 2014). One of the disadvantages of NBPT molecule is its instability under acidic conditions, high temperature and humidity, which is in part, is caused by the solvent used for NBPT dissolution before mixing with the urea in the fertilizer industry (Omilinsky et al., 1997; Sutton et al., 2013; Gabrielson et al., 2014; Whitehurst; Whitehurst, 2014).
The types of industrial finishing process of urea, granular or prilled, did not significantly influence $(\mathrm{p} \leq 0.05)$ cumulative $\mathrm{N}-\mathrm{NH}_{3}$ losses(Figure 5). The cumulative $\mathrm{N}-\mathrm{NH}_{3}$ loss of prilled urea ( $38 \%$ of the applied $\mathrm{N}$ ) was similar to that of granular urea ( $39 \%$ of the applied $\mathrm{N})$, with daily peaks of $\mathrm{N}-\mathrm{NH}_{3}$ loss, in both prilled and granular, on the $2^{\text {nd }}$ day after topdressing application (Figure 4b). Prilled urea has smaller granules ( 1 to $2 \mathrm{~mm}$ ), when compared with the granular urea (3 to $4 \mathrm{~mm}$ ); it also has higher dissolution rate in the soil, due to its greater specific surface area and water absorption from the atmosphere (hygroscopicity), which are factors that did not influence $\mathrm{N}_{-} \mathrm{NH}_{3}$ loss.

$U$ rea incorporated at $0.02 \mathrm{~m}$ depth promoted cumulative $\mathrm{N}-\mathrm{NH}_{3}$ loss of $23.8 \%$ of the applied $\mathrm{N}$. The mechanical incorporation process of urea, even at inadequate depth $(0.02 \mathrm{~m})$, was more effective in reducing $\mathrm{N}-\mathrm{NH}_{3}$ loss when compared with the application of urea coated with $16 \% \mathrm{~S}^{0}$ (32.1\% of $\mathrm{N}$ applied ), and blend of PSCU and urea (31.8\% of the $\mathrm{N}$ applied). The mean value of cumulative $\mathrm{N}-\mathrm{NH}_{3}$ loss (4 evaluations) of $1.1 \%$ of the applied $\mathrm{N}$ was reported with the incorporation of urea at 0.15 to $0.20 \mathrm{~m}$ depth (Fontoura; Bayer, 2010).

Urea coated with $16 \% \mathrm{~S}^{0}$, or with $7.9 \% \mathrm{~S}^{0}+$ polymers ("blends" of $30 \%$ conventional urea with $70 \%$ urea coated with $7.6 \% \mathrm{~S}^{0}+$ polymer) did not promote significant difference $(\mathrm{p} \leq 0.05)$ in cumulative $\mathrm{N}-\mathrm{NH}_{3}$ loss, when compared with each other. However, they promoted reduction in $\mathrm{N}-\mathrm{NH}_{3}$ loss when compared with prilled and granular urea (Figure 5).

In corn crops in soil with build up fertility, significant difference was found $(\mathrm{p} \leq 0,05)$ in cumulative $\mathrm{N}-\mathrm{NH}_{3}$ loss of urea (31.2\% of the $\mathrm{N}$ applied in topdressing), when compared with urea $+7.9 \% \mathrm{~S}^{0}+$ polymers ("blends" of conventional urea coated with $7.6 \% \mathrm{~S}^{0}+$ polymer) $(19.6 \%)$. The percentage of reduction in $\mathrm{N}^{-\mathrm{NH}_{3}}$ losses of the physical mixture of urea and PSCU was $37.2 \%$, when compared with the application of conventional urea. This occurred because the coated fertilizer fraction provide better synchrony between the release of the $\mathrm{N}$ of the urea and the absorption by the plant (Azeem et al., 2014; Cancellier et al., 2016).

U rea + thermoplastic resin $(3.1 \%$ of total $\mathrm{N}$ applied), ammonium sulfate (1.1\%), and ammonium nitrate $(0.7 \%)$ showed no significant differences $(p \leq 0.05)$ between each other, and provided smaller cumulative $\mathrm{N}-\mathrm{NH}_{3}$ loss (Figure 5).

The lowest value of the cumulative $\mathrm{N}-\mathrm{NH}_{3}$ loss of the urea coated with thermoplastic resin applied to 23.84 $\mu \mathrm{m}$ thick layer (Figure 2) is due to the process of $\mathrm{N}$ release from fertilizer granule to the soil solution. This process 
involves diffusion of soluble fertilizer of the inner granule (urea) to the soil solution, by the pores in the polyurethane chain. Due to the increase in the vapor pressure, water penetrates the polyurethane resin (plastic) and increases the osmotic pressure inside the granule, promoting diffusion gradient, which is influenced mainly by temperature and humidity (Fick's law). In addition, there is the flexibility in the polyurethane coating membrane and increase in pore size, which facilitates the diffusion of the fertilizer to the soil solution (Azeem et al., 2014; Timilsena et al., 2014; Naz; Sualiman, 2016).

For the ammoniacal fertilizers (sulfate and ammonium nitrate), with acidic or neutral reaction in soil, $\mathrm{N}-\mathrm{NH}_{3}$ loss was lower, since the ammonium ion remained in the ionic form $\mathrm{N}-\mathrm{NH}_{4}{ }^{+}$, i.e., it did not convert to $\mathrm{N}-\mathrm{NH}_{3}$ in soil at $\mathrm{pH}<7.0$ (Cantarella; Nitrogênio; Novais, 2007).

Previous studies carried out with ammonium sulfate and ammonium nitrate in corn and sugar cane al so reported lower $\mathrm{N}-\mathrm{NH}_{3}$ loss from ammoniacal sources of $\mathrm{N}$ when compared with urea (Fontoura; Bayer, 2010; Nascimento et al., 2013; Stafanato et al., 2013).

Different results were reported in works carried out in the South Central region of the state of Paraná in four corn crops cul tivated under no-tillage system (mean of four eval uations) of the cumulative $\mathrm{N}-\mathrm{N} \mathrm{H}_{3}$ losses: $12.5 ; 6.6 ; 1.9$; 1.1 ; and $1.0 \%$ for urea, urea + NBPT, ammonium sulfate, urea incorporated at 0.15-0.20 m depth; and ammonium nitrate, respectively (Fontoura; Bayer, 2010).

Currently, the cost of a $\mathrm{N}$ unit derivative from urea in Brazil, is approximately R\$ 1.78 or US\$0,56 (1 ton of urea $(45 \% \mathrm{~N}=\mathrm{US} \$ 153.00$ and $1 \mathrm{US} \$=\mathrm{R} \$ 3,1678)$. Thus, losses of $59 \mathrm{~kg} \mathrm{ha}^{-1} \mathrm{~N}-\mathrm{NH}_{3}$, such as that which occurred with conventional urea (Figure 5) provided extra expenditure of R $\$ 105.00$ or US $\$ 33.00$ in production costs related to $\mathrm{N}$ fertilization, excluding the costs with transportation and application.

In this context, it must be said that for the proper choice of the $\mathrm{N}$ fertilizer to be used in agricultural areas, economic and technical aspects should be taken into account for the calculation of the effective cost of $\mathrm{N}$ unit (price per ton of $\mathrm{N}$ fertilizer on the property/ $\mathrm{N}$ concentration), since potential N-N H 3 loss of the urea applied to the surface ( $39 \%$ of the total applied N) are significant in comparison with ammonium nitrate $(0.7 \%$ of the applied N), for instance. Thus, a more realistic calculation of the effective cost of a $\mathrm{N}$ unit cost must be carried out according to the following equation: $\mathrm{N}$ Effective Cost (price per ton of $\mathrm{N}$ fertilizer on farm $/ \mathrm{N}$ concentration in the fertilizer - mean $\mathrm{N}$ loss by volatilization of the fertilizer in the application conditions).

\section{Dailyand total carbon dioxide $\left(\mathrm{CO}_{2}\right)$ emissions}

Daily $\mathrm{CO}_{2}$ flows were influenced significantly ( $\mathrm{p} \leq 0.05$ ) by conventional, stabilized and controlled release $\mathrm{N}$ fertilizers applied in topdressing in corn summer crop (Figure 6).

The largest daily flows of $\mathrm{CO}_{2}$ from $\mathrm{N}$ fertilizers, except for hydrolyzed leather, occurred in the first four days after yoursapplication, and coincided with the greatest daily $\mathrm{N}-\mathrm{NH}_{3}$ losses (Figure 4b).

On the $1^{\text {st }}$ day, prilled urea; blend of PSCU and urea; urea + thermoplastic resin; and ammonium nitrate promoted daily $\mathrm{CO}_{2}$ emissions equal to $150,137,114$ and $95 \mathrm{~kg} \mathrm{ha}^{-1} \mathrm{~d}^{-1}$, respectively. On the $3^{\text {rd }}$ day, sulfur urea coated; incorporated urea; granular urea; and urea + NBPT presented peak of $\mathrm{CO}_{2}$ emission of $177,171,150$, and 133 $\mathrm{kg} \mathrm{ha}^{-1} \mathrm{~d}^{-1}$. The $\mathrm{CO}_{2}$ emission decreased after the $4^{\text {th }}$ day, and increased after the $10^{\text {th }}$ day.

A fter urea hydrolysis, by the action of urease in soils with $\mathrm{pH}<6.3, \mathrm{CO}_{2}$ is released to the atmosphere. However, the higher $\mathrm{CO}_{2}$ emission is due to the increased activity of urease in conjunction with weather conditions, temperature and soil moisture, which are al so factors that contribute to higher volatilization of $\mathrm{N}^{-\mathrm{NH}_{3}}$ (Cantarella; Nitrogênio; Novais, 2007). The two main environmental factors that govern $\mathrm{CO}_{2}$ flows are temperature and soil moisture (A ndres et al., 2012).

No significant differences were found $(\mathrm{p}>$ 0.05 ) in cumulative emissions of $\mathrm{CO}_{2}$ in the control treatment (without fertilizer application) for ammonium nitrate (no carbon in the composition) applied at doses of 90,180 and $225 \mathrm{~kg} \mathrm{ha}^{-1} \mathrm{~N}$. The activity of soil microorganisms also controls $\mathrm{CO}_{2}$ emissions. The effect of $\mathrm{N}$ applied to the soil and its influence in the activity of the microorganisms are divergent. No influence of $\mathrm{N}$ fertilizer was found in the soil microbiological activity in a corn-soybean rotation system (Willson; Paul; Harwood, 2001).

Study in three agricultural areas in which $\mathrm{CO}_{2}$ emissions were evaluated, in the control treatment without application of $\mathrm{N}$ fertilizers, higher $\mathrm{CO}_{2}(4 \mathrm{Mg}$ $\mathrm{ha}^{-1}$ ) were reported, when compared with the ammonium nitrate applied at a dose of $225 \mathrm{~kg} \mathrm{ha}^{-1} \mathrm{~N}$. A ccording to these authors (Al-Kaisi et al., 2008), the effect of $\mathrm{N}$ fertilization is inconsistent and highly related to soil and climatic conditions of the agricultural area. On the other hand, (Dick, 1992) reports that the soil microbial activity may increase with $\mathrm{N}$ fertilization, due to the increase in the production of plants biomass, which stimulates soil biological activity. 

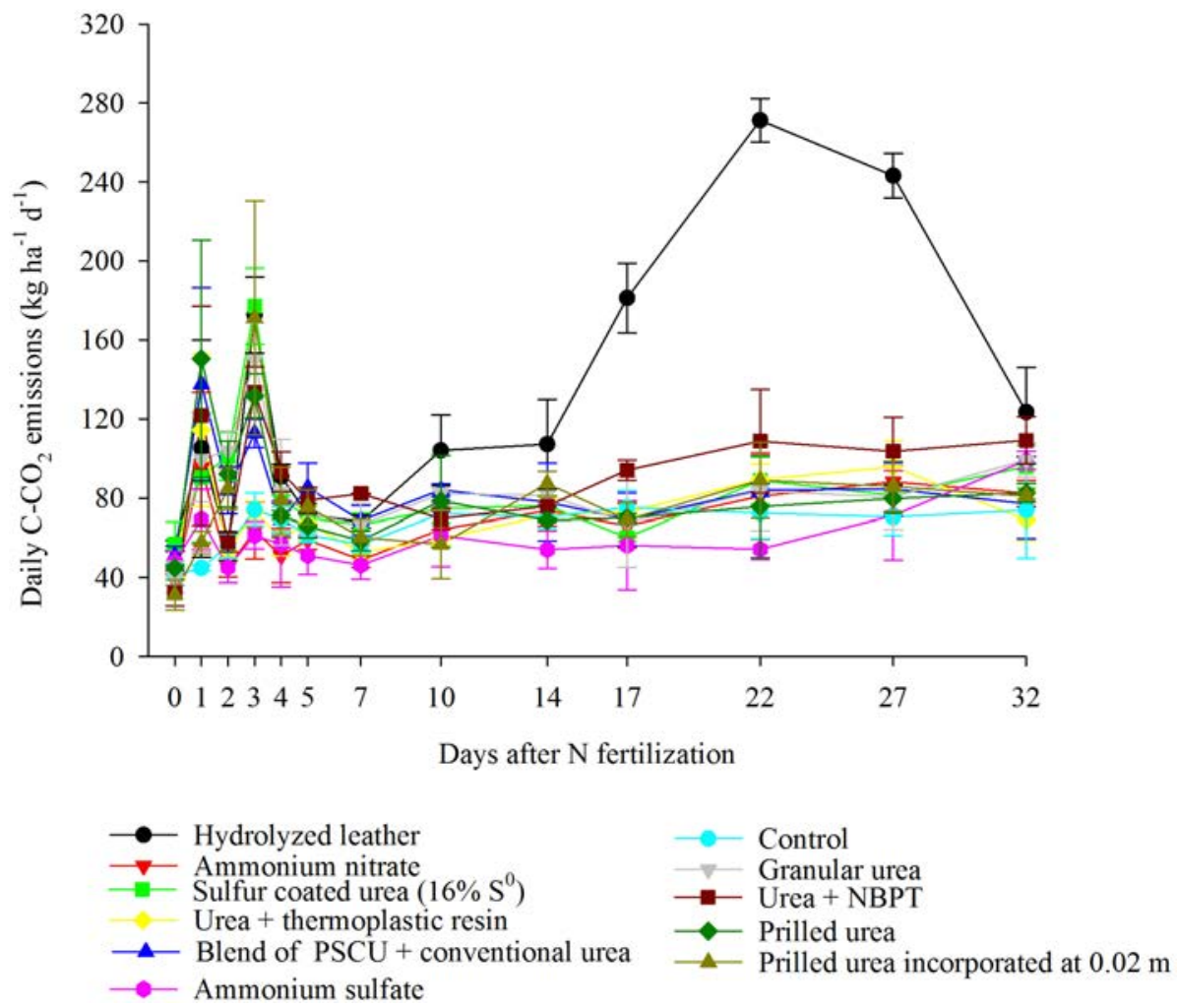

Figure 6: Daily $\mathrm{CO}_{2}$ emissions after 32 days after the application of conventional, stabilized and controlled release $\mathrm{N}$ fertilizers in summer corn crop. The vertical bars represent the standard error of the means $(n=3)$.

Hydrolyzed leather presented a peak in $\mathrm{CO}_{2}$ emission on the $22^{\text {th }}$ day, and in ammonium sulfate only after 32 days, with values of 271 and $99 \mathrm{~kg} \mathrm{ha}^{-1} \mathrm{~d}^{-1}$, respectively (Figure 6). The increase in the values of daily $\mathrm{N}-\mathrm{NH}_{3}$ losses (Figure $4 \mathrm{~b})$ of hydrolyzed leather coincided with the increase of $\mathrm{CO}_{2}$ emissions, emphasizing the occurrence of $\mathrm{N}$ mineralization due to the decomposition of organic compounds present in hydrolyzed leather in relation to $\mathrm{C} / \mathrm{N}$ of $3 / 1$ (Table 2). In materials with $\mathrm{C}: \mathrm{N}<30 / 1$, such as hydrolyzed leather, there is predominant $\mathrm{N}$ mineralization.

The total $\mathrm{CO}_{2}$ emission in 32 days was influenced significantly $(\mathrm{p} \leq 0.05)$ by the conventional, stabilized and controlled release $\mathrm{N}$ fertilizers in summer corn crop (Figure 7).

Total $\mathrm{CO}_{2}$ emissions by conventional, stabilized and controlled release $\mathrm{N}$ fertilizers in descending order was: $\left(5,287 \mathrm{~kg} \mathrm{ha}^{-1} \mathrm{CO}_{2}\right)>$ urea $+\operatorname{NBPT}\left(3,270 \mathrm{~kg} \mathrm{ha}^{-1}\right.$ $\left.\mathrm{CO}_{2}\right)=$ granular urea $\left(3,023 \mathrm{~kg} \mathrm{ha}^{-1} \mathrm{CO}_{2}\right)=$ incorporated prilled urea $\left(2,942 \mathrm{~kg} \mathrm{ha}^{-1} \mathrm{CO}_{2}\right)=$ blend of PSCU and urea $\left(2,869 \mathrm{~kg} \mathrm{ha}^{-1} \mathrm{CO}_{2}\right)=$ prilled urea $\left(2,858 \mathrm{~kg} \mathrm{ha}^{-1} \mathrm{CO}_{2}\right)$ $=$ urea coated with $16 \% \mathrm{~S}^{0}\left(2,722 \mathrm{~kg} \mathrm{ha}^{-1} \mathrm{CO}_{2}\right)>$ urea
+ thermoplastic resin $\left(2,481 \mathrm{~kg} \mathrm{ha}^{-1} \mathrm{CO}_{2}\right)=$ ammonium nitrate $\left(2,364 \mathrm{~kg} \mathrm{ha}^{-1} \mathrm{CO}_{2}\right)=$ control $\left(2,383 \mathrm{~kg} \mathrm{ha}^{-1} \mathrm{CO}_{2}\right)$ $=$ ammonium sulfate $\left(2,332 \mathrm{~kg} \mathrm{ha}^{-1} \mathrm{CO}_{2}\right)$.

Taking the granular urea as reference with a percentage value of $(100 \%)$, the total $\mathrm{CO}_{2}$ emissions in $\mathrm{kg}$ $\mathrm{ha}^{-1}$ by the treatments applied in topdressing in corn were: $175,108,100,97,95,95,90,82,79,78$ and $77 \%$ for hydrolyzed leather, urea + NBPT, incorporated urea, blend of PSCU and urea, prilled urea, urea coated with $16 \% \mathrm{~S}^{0}$, urea + thermoplastic resin, ammonium nitrate, control, and ammonium sulfate, respectively.

When subtracting the values $\left(\mathrm{kg}\right.$ of $\left.\mathrm{CO}_{2}\right)$ emitted from the hydrolyzed leather, urea + NBPT, granular urea, incorporated prilled urea, blend of PSCU and urea, prilled urea, and urea coated with $16 \% \mathrm{~S}^{0}$ with the emission of the control, it was obtained the following values of total $\mathrm{CO}_{2}$ emissions in 32 days after the application of $\mathrm{N}$ fertilizers: 2,093; 887; 640; 559; 486; 475; and $339 \mathrm{~kg} \mathrm{ha}^{-1} \mathrm{CO}_{2}$ respectively. U rea + thermoplastic resin promoted the lowest value of total $\mathrm{CO}_{2}$ emission, equal to $98 \mathrm{~kg} \mathrm{ha}^{-1}$. 


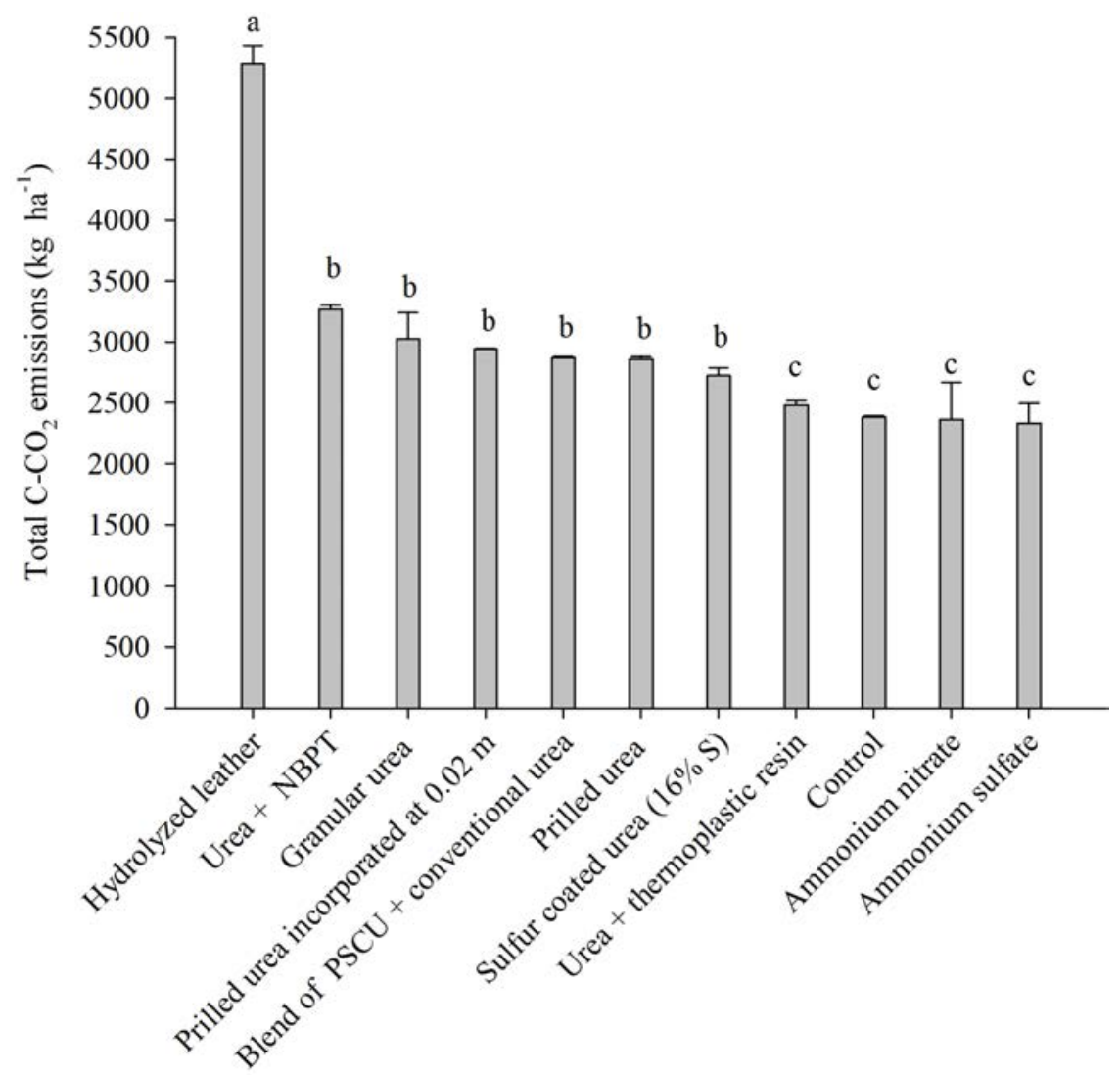

Figure 7: Cumulative $\mathrm{CO}_{2}$ emissions after 32 days after the application of conventional, stabilized and controlled $\mathrm{N}$ fertilizers in summer corn crop. Equal letters do not differ from one another by the Skott-Knott test at 5\% significance. The vertical bars represent the standard error of the means $(n=3)$.

It is clear that this amount of $\mathrm{CO}_{2}$ is derivative from the carbon industrially fixed in the urea during the industrial production process and due to the decomposition in the case of hydrolyzed leather (Table 2). With the application of nitrate and ammonium sulfate, without $\mathrm{C}$ in the chemical composition, $\mathrm{CO}_{2}$ emissions were similar to the control treatment, and lower than those of urea (except for urea + plastic resin) and of hydrolyzed leather, which were all applied at the same dose of $150 \mathrm{~kg}$ ha $\mathrm{N}$, discarding the hypothesis that the $\mathrm{CO}_{2}$ emitted is derivative only from the activity of soil micro-organisms. A fter urea hydrolysis in the soil by the action of urease, $\mathrm{CO}_{2}$ is also released, which was fixed during the urea production process by means of the reaction between ammonia and carbon dioxide. According to the IPCC (2006), the C emission factor due to the application of urea is 0.20 , i.e., for every $100 \mathrm{~kg}$ of urea applied, $20 \mathrm{~kg} \mathrm{C}$ is emitted to the atmosphere, corresponding to $73.3 \mathrm{~kg} \mathrm{CO}_{2}$.

\section{CONCLUSIONS}

$\mathrm{N}-\mathrm{NH}_{3}$ losses of conventional urea (granular or prilled) occur with greater intensity until the $4^{\text {th }}$ day of its application in topdressing to the soil. The cumulative $\mathrm{N}-\mathrm{NH}_{3}$ loss by conventional, stabilized and controlled release $\mathrm{N}$ fertilizers in descending order was: Granular Urea $=$ prilled urea $>$ urea coated with $16 \% \mathrm{~S}^{0}=$ blend of PSCU and urea $>$ incorporated prilled urea $>$ urea + $\mathrm{NBPT}=$ hydrolyzed leather $>$ urea + thermoplastic resin = ammonium sulfate $=$ ammonium nitrate. The types of industrial finishing process of urea, granular or prilled, do not influence the $\mathrm{N}-\mathrm{NH}_{3}$ losses. The sulfate and ammonium nitrate, and the urea + thermoplastic resin reduce carbon dioxide emissions in corn summer crop. On the other hand, leather hydrolyzed, for containing organic carbon in its composition, promotes higher total $\mathrm{C}-\mathrm{CO}_{2}$ emission to the atmosphere. 


\section{ACKNOWLEDGMENTS}

The authors thank the Research Foundation of Minas Gerais (FAPEMIG) for the financial support, and the National Research and Development Council (CNPq), for the scholarship.

\section{REFERENCES}

ABALOS, D. et al. Meta-analysis of the effect of urease and nitrification inhibitors on crop productivity and nitrogen use efficiency. Agriculture, Ecosystems and Environment,189:136-144. 2014.

ALONSO-AYUSO, M.; QUEMADA, G. M. Nitrogen use efficiency and residual effect of fertilizers with nitrification inhibitors. European Journal of Agronomy, 80:1-8, 2016.

ANDRES, R. J. et al. Synthesis of carbon dioxide emissions from fossil-fuel combustion. Biogeosciences, 9:1845-71, 2012.

AZEEM, B. et al. Review on materials and methods to produce controlled release coated urea fertilizer. Journal Control Release, 181:11-21, 2014.

AL-KAISI, M.; KRUSE, M.; SAWYER, J. E. Effect of nitrogen fertilizer application on growing season soil carbon dioxide emission in a corn-soybean rotation. Journal of Environmental Quality, 37:325-332, 2008.

BLOUIN, G. M. Method of making sulfur-coated fertilizer pallet having a controlled dissolution rate. US Pat 3295950, 1967. 7p.

BLOUIN, G. M.; RINDT, D. W.; MOORE, O. E. Sulfur-coated fertilizers for controlled release. Pilot-plant production. Journal of Agricultural and Food Chemistry, 19:801-808, 1971.

BYRNES, B. H.; FRENEY, J. R. Recent developments on the use of urease inhibitors in the tropics. Fertility Research, 42:251-259, 1995.

BOARETTO, R. M. et al. Absorption of ${ }^{15} \mathrm{NH}_{3}$ volatilized from urea by Citrus trees. Plant and Soil, 365:283-290, 2013.

CANCELLIER, E. L. et al. Ammonia volatilization from enhancedefficiency urea on no-till corn in Brazilian cerrado with improved soil fertility. Ciência e Agrotecnologia, 40:1523, 2016.

CANTARELLA, H. Nitrogênio. In: NOVAIS, R. F. et al. (eds.) Fertilidade do Solo. Viçosa, MG: Sociedade Brasileira de Ciência do Solo, p.375-470, 2007.
CANTARELLA, $\mathrm{H}$. et al. Ammonia volatilization from urease inhibitor-treated urea applied to sugar cane trash blankets. Scientia Agricola, 65:397-340, 2008.

CHIEN, S. H.; PROCHNOW, L. I.; CANTARELLA, H. Recent developments of fertilizer production and use to increase nutrient efficiency and minimize environmental impacts. Advances in Agronomy, 102:261-316. 2009.

COMISSÃO DE FERTILIDADE DO SOLO DO ESTADO DE MINAS GERAIS - CFSEMG. Recomendações para o uso de corretivos e fertilizantes em Minas Gerais - $5^{\text {a }}$ Aproximação. Viçosa, MG: Folha Viçosa; 1999, p.21-24.

CREASON, G. L.; SCHMITT, M. R.; HENDRICKSON, L. L. Urease inhibitory associated with $\mathrm{N}$-(nbutyl) thiophosphophoric triamide is due to formation of its oxon analog. Soil Biology Biochemistry, 22:209-211,1990.

DAWAR, K. et al. Urease inhibitor reduced $\mathrm{N}$ losses and improves plant bio-availability of urea applied in fine particle and granulated forms under field conditions. Agriculture, Ecosystem and Environment, 144:41-5, 2011.

DAVIDSON, D. G. U. F. X. Materials for sustained and controlled release of nutrients and molecules molecules to support plant growth. Journal of Agricultural and Food Chemistry, 60:870-876, 2012.

DENMEAD, O. T.; FRENEY, J. R.; DUNIN, F. X. Gas exchange between plant canopies and the atmosphere: Case studies for ammonia. Atmosphere Environment, 42:3394-3406, 2008.

DETRICK, J. H.; HARGROVE, G. L. Polymer-sulfur-polymer coated fertilizers, US Pat. 6,338,746 B1, 2002. 6p.

DICK, R. P. A review: Long-term effects of agricultural systems on soil biochemical and microbial parameters. Agriculture, Ecosystem and Environment, 40:25-36, 1992.

DOMINGUEZ, M. J. et al. Design, synthesis, and biological evaluation of phosphoramide derivatives as urease inhibitors. Journal of Agricultural and Food Chemistry, 56:3721-3731, 2008.

ENGEL, R.; JONES, C.; WALLANDER, R. Ammonia volatilization from urea and mitigation by NBPT following surface application to cold soils. Nutrient Management and Soil and Plant Analysis, 75:2348-2357, 2011.

FERNÁNDEZ, F. G.; TERRY, R. E.; CORONEL, E. G. Nitrous oxide emissions from anhydrous ammonia, urea, and polymercoated urea in Illinois cornfield. Journal of Environmental Quality, 44:415-422, 2015. 
FERREIRA, D. F. Sisvar: A computer statistical analysis system. Ciência e Agrotecnologia, 35(6):1039-1042, 2011.

FERSCH, K. E.; STEARNS, W. E. Controlled release fertilizer. US Pat. 4042366, 1977. 7p.

FIXEN, P. E. Can we define a global framework within wich fertilizer best management practice can be adapted to local conditions? In: Fertilizer Best Management Practices. IFA International Workshop on Fertilizer Best Management Practices (FBMPs). March; Paris. Paris: IFA; 2007. p.74-85.

FONT, M. et al. Structural characteristics of phosphoramide derivatives as urease inhibitors: Requirements of activity. Journal of Agricultural and Food Chemistry, 56:84518460, 2008.

FONTOURA, S. M. V.; BAYER, C. Ammonia volatilization in no-till in the south-central region of the state of Paraná, Brazil. Revista Brasileira de Ciência do Solo, 34:1677-1684, 2010.

GABRIELSON, K. D. et al. Liquid compositions containing urease inhibitors and glycol alkyl ethers and methods of making use thereof. US Pat. 2014/0047883, 2014. 10p.

$\mathrm{GAO}, \mathrm{X}$. et al. Enhanced efficiency urea sources and placement effects on nitrous oxide emissions. Agronomy Journal, 107: 265-277, 2015.

GENG, J. et al. Synchronized relationships between nitrogen release of controlled release nitrogen fertilizers and nitrogen requirements of cotton. Field Crops Research, 184:9-16, 2015.

GOERTZ, H. M.; TIMMONS, R. J.; MCVEY, G. R. Sulfur coated fertilizers and process for the preparation threof. US Pat. 5.219.465, 1993. 23p.

GROHS, M. et al. Resposta do arroz irrigado ao uso de inibidor de urease em plantio direto e convencional. Ciência e Agrotecnologia, 35:336-345, 2011.

HALVORSON, A. D. et al. Enhanced-efficiency nitrogen fertilizers: Potential role in nitrous oxide emission mitigation. Agronomy Journal, 106:715-722, 2014.

HOLCOMB, J. C. et al. Effect of irrigation rate on ammonia volatilization. Soil Science Society of American Journal, 75:2341-2347, 2011.

HUDSON, A. P. Sealants for fertilizer compositions containing natural waxes. US Pat. 5478375, 1995. 9p.

HUDSON, A. P. Sulfur coated fertilizers with improved abrasion resistance. US Pat. 5984994, 1999. 8p.
THE INTERNATIONAL FERTILIZER INDUSTRY ASSOCIATION - IFA. The global "4R" nutrient stewardship framework for developing and delivering fertilizer best management practices. Paris: 2009. 10p.

INTERGOVERNMENTAL PANEL ON CLIMATE CHANGE - IPCC. The physical science basis: Summary for policymakers. Contribution of working group I to the fourth assessment report of the intergovernmental panel on climate change. Cambridge: Cambridge University Press; 2006. p.5-53.

LARA CABEZAS, W. A. R. et al. Calibration of a semi-open static collector for determination of ammonia volatilization from nitrogen fertilizers. Communications in Soil Science and Plant Analysis, 30:389-406, 1999.

$\mathrm{LI}, \mathrm{H}$. et al. Ammonia volatilization from urea in rice fields with zero-drainage water management. Agricultural Water Manage, 95:887-894, 2008.

MANUZA, B. et al. The binding mechanism of urea, hydroxamic acid and $N$-( $n$-butyl)-phosphoric triamide to the urease active site. A comparative molecular dynamics study. Soil Biology and Biochemistry, 31:789-796, 1999.

NASCIMENTO, C. A. C. et al. Ammonia volatilization from coated urea forms. Revista Brasileira de Ciência do Solo, 37:1057-1063, 2013.

NAZ, Y. M.; SULAIMAN, S. A. Slow release coating remedy for nitrogen loss from conventional urea: A review. Journal of Controlled Release, 225:109-120, 2016.

OMILINSKY, B. A. et al. Formulation for fertilizer additive concentrate. US Pat 5698003, 1997. 7p.

PEREIRA, H. S. et al. Ammonia volatilization of urea in the outof-season corn. Revista Brasileira de Ciência do Solo, 33:1685-94, 2009.

PHONGPAN, S. et al. Use of phenyl phosphorus diamidate and $\mathrm{N}$-(n-butyl) thiophosphorictriamide to reduce ammonia loss and increase grain yield following application of urea to flooded rice. Fertilizer Research, 41:59-66, 1995.

RAWLUK, C. D. L.; GRANT, C. A.; RACZ, G. J. Ammonia volatilization from soils fertilized with urea and varying rates of urease inhibitor NBPT. Canadian Journal of Soil Science, 81:239-346, 2001.

ROCHETTE, P. et al. Banding of urea increased ammonia volatilization in a dry acidic soil. Journal Environmental Quality, 38:1383-1390, 2009. 
ROCHETTE, P. et al. Ammonia volatilization an nitrogen retention: How deep to incorporate urea? Journal of Environmental Quality, 42:1635-1642, 2014.

RUSER, R.; SCHULZ, R. The effect of nitrification inhibitors on the nitrous oxide $\left(\mathrm{N}_{2} \mathrm{O}\right)$ release from agricultural soils-a review. Journal of Plant Nutrition and Soil Science, 178:171-188, 2015.

SANTOS, H. G. et al. Sistema brasileiro de classificação de solos. $3^{a}$. ed. Brasília, DF: Embrapa; 2013. 353p.

SHIRLEY JUNIOR, A. R.; MELINE, R. S. Production of slow release nitrogen fertilizers by improved method of coating urea with sulfur. US Pat. 3903333, 1975. 34p.

SILVA, A. G. B. et al. Urease inhibitor NBPT on ammonia volatilization and crop productivity: A meta-analysis, Agronomy Journal, 109:1-13, 2016.

SOAUD, A. A. et al. Effect of elemental sulfur application on ammonia volatilization from surface applied urea fertilizer to calcareous sandy soils. Australian Journal of Crop Science, 5:611-619, 2011.

STAFANATO, J. B. et al. Volatilização de amônia oriunda de ureia pastilhada com micronutrientes em ambiente controlado. Revista Brasileira de Ciência Solo, 37:726-732, 2013.

SUTTON, A. R.; THORNSBERRY, W. Additive containing N-(Nbutil) thiophosphoric triamide for urea base fertilizer. US Pat. 2013/0283873, 2013. 4p.

TIMILSENA, Y. P. et al. Enhanced efficiency fertilizers: A review of formulation and nutrient release patterns. Journal of the Science of Food and Agriculture, 95:1131-1142, 2014.

TIMMONS, R. J.; GOERTZ, H. M. Processes for the preparation of sulfur coated fertilizers and products produced thereby. US Pat. 5405426, 1995. 16p.
TRENKEL, M. E. Slow and controlled-release and stabilized fertilizers: An option for enhancing nutrient use efficiency in agriculture. Paris: International Fertilizer Industry Association; 2010. 163p.

VAN GRINSVEN, H. J. N. et al. Losses of ammonia and nitrate from agriculture and their effect on nitrogen recovery in the Europen Union and the United States between 1900 and 2050. Journal of Environmental Quality, 44:356$367,2015$.

WATANABE, A. et al. Permeation of urea through various polyurethane membranes. Pest Management Science, 65:1233-1240, 2009.

WATSON, C. J. et al. Rate and mode of application of the urease inhibitor $N$-(n-butyl) thiophosphoric triamide on ammonia volatilization from surface-applied urea. Soil Use and Management, 24:246-253, 2008.

WHITEHURST, G. B.; WHITEHURST, B. H. NBPT solution for preparing urease inhibited urea fertilizers prepared from N-ALKYL; N-ALKYL; AND N-ALKYL-N-ALKYLOXY amino alcohols. US Pat. 2010/0037570, 2014. 29p.

WILLSON T, C.; PAUL. E. A. A.; HARWOOD, R. R. Biologically active soil organic matter fractions in sustainable cropping systems. Applied Soil Ecology, 16:63-76, 2001.

WU, L.; LIU, M. Preparation and properties of chitosan-coated NPK compound fertilizer with controlled-release and waterretention. Carbohydrate Polymers, 72:240-247, 2008.

YAMAMOTO, C. F. et al. Slow release fertilizer based on urea/ urea-formaldehyde polymer nanocomposites. Chemical Enginnering Journal, 287:390-397, 2016. 